\title{
A Kiss to drive rhythms in reproduction
}

\section{Valérie Simonneaux $(\mathbb{C}$}

Institut des Neurosciences Cellulaires et Intégratives, CNRS, Université de Strasbourg, Strasbourg, France

\section{Correspondence}

Valérie Simonneaux, Institut des

Neurosciences Cellulaires et Intégratives, CNRS, Université de Strasbourg,

Strasbourg, France.

Email: simonneaux@inci-cnrs.unistra.fr

\begin{abstract}
Reproduction, like many other biological functions, exhibits marked daily and seasonal rhythms in order to anticipate and adapt breeding activity to environmental challenges. In recent years, studies investigating the neuroendocrine mechanisms driving rhythms in reproduction have unveiled the pivotal role of hypothalamic neurons expressing kisspeptin in integrating and forwarding daily and seasonal cues to the reproductive system. The objective of this review is to summarize the knowledge on the effect and role of this neuropeptide on the mammalian hypothalamo-pituitarygonadal axis and describe how it is involved in the daily control of ovulation in females and long-term adaptation of reproduction in seasonal breeders.
\end{abstract}

\section{K E Y W O R D S}

clock, daily rhythm, GnRH, LH, melatonin, RFRP-3, seasonal rhythm, T3, vasopressin

\section{I INTRODUCTION}

Adaptation of reproductive activity to various intrinsic and extrinsic factors is pivotal to insure breeding success and offspring survival. Therefore, the activity of the whole reproductive system, from the brain to the gonads, is sensitive to various signals including age, metabolism, stress, and hormonal milieu. Geophysical cues, notably the daily and seasonal changes in light intensity and duration, also are essential information that need to be taken into account by an organism to optimize reproduction according to temporal constraints. Thus, in mammals, reproductive system activation, notably in females, is highest at the end of the resting period, a time of maximal arousal and activity which facilitates reproductive success (Kriegsfeld, 2013; Simonneaux \& Bahougne, 2015 for reviews). Mammals are also responsive to the seasonal changes in light, temperature, and food resources, and most of them, notably those leaving in the wild, adapt their breeding activity to insure the birth and weaning of the offspring at a time of optimal temperature and food resources to improve their survival (Hazlerigg \& Simonneaux, 2015; Lincoln \& Short, 1980 for reviews). Our understanding of how mammals integrate geophysical cues has improved with the discovery of endogenous circadian clocks (Mohawk, Green, \& Takahashi, 2012 for review) and the synchronizing property of the seasonal rhythm by the pineal hormone melatonin (Bartness, Powers, Hastings, Bittman, \& Goldman, 1993; Reiter, 1993 for reviews). However, linking these daily and seasonal signals to the reproductive system, notably to the neurons expressing gonadotropin releasing hormone $(\mathrm{GnRH})$ known to act as a central driver of the gonadotropic axis (Guillemin, 1977; Schally et al., 1970) has been challenging. The discovery, in 2003, that the hypothalamic neuropeptide kisspeptin (Kp) and its cognate receptor Kiss1R are mandatory for puberty onset and functional reproduction (de Roux

\footnotetext{
Abbreviations: ARC, arcuate nucleus; AVPV, anteroventral periventricular area around the 3rd ventricle; Dio2 or 3, deiodinase 2 or 3; DMH, dorsomedial hypothalamus; E2, estradiol; Er $\alpha$ or $\beta$, estradiol receptor of $\alpha$ or $\beta$ subtype; FSH, follicle-stimulating hormone; GnRH, gonadotropin releasing hormone; Kiss1R or GPR54, kisspeptin receptor; KNDys neurons, neurons expressing kisspeptin, neurokinin B \& dynorphin; Kp, kisspeptin; LD, long day; LH, luteinizing hormone; MT1 or MT2, melatonin receptor subtype 1 or 2; OVX, ovariectomy; POA, preoptic area; PT, pars tuberalis; RFRP-3, Arg-Phe related peptide-3; SCN, suprachiasmatic nuclei; SD, short day; T3, triiodothyronine; T4, thyroxine; TR $\alpha$, thyroid hormone receptor of $\alpha$ subtype; TSH, thyroid stimulating hormone; V1a receptors, vasopressin receptor; VIP, vasoactive intestinal peptide; VPAC2, vasoactive intestinal peptide receptor.
}

Edited by Rae Silver. Reviewed by Hugues Dardente and Michael Lehman.

All peer review communications can be found with the online version of the article. 


\section{Seasonal} input

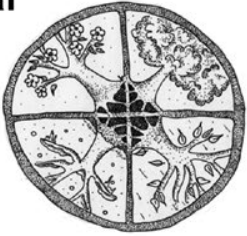

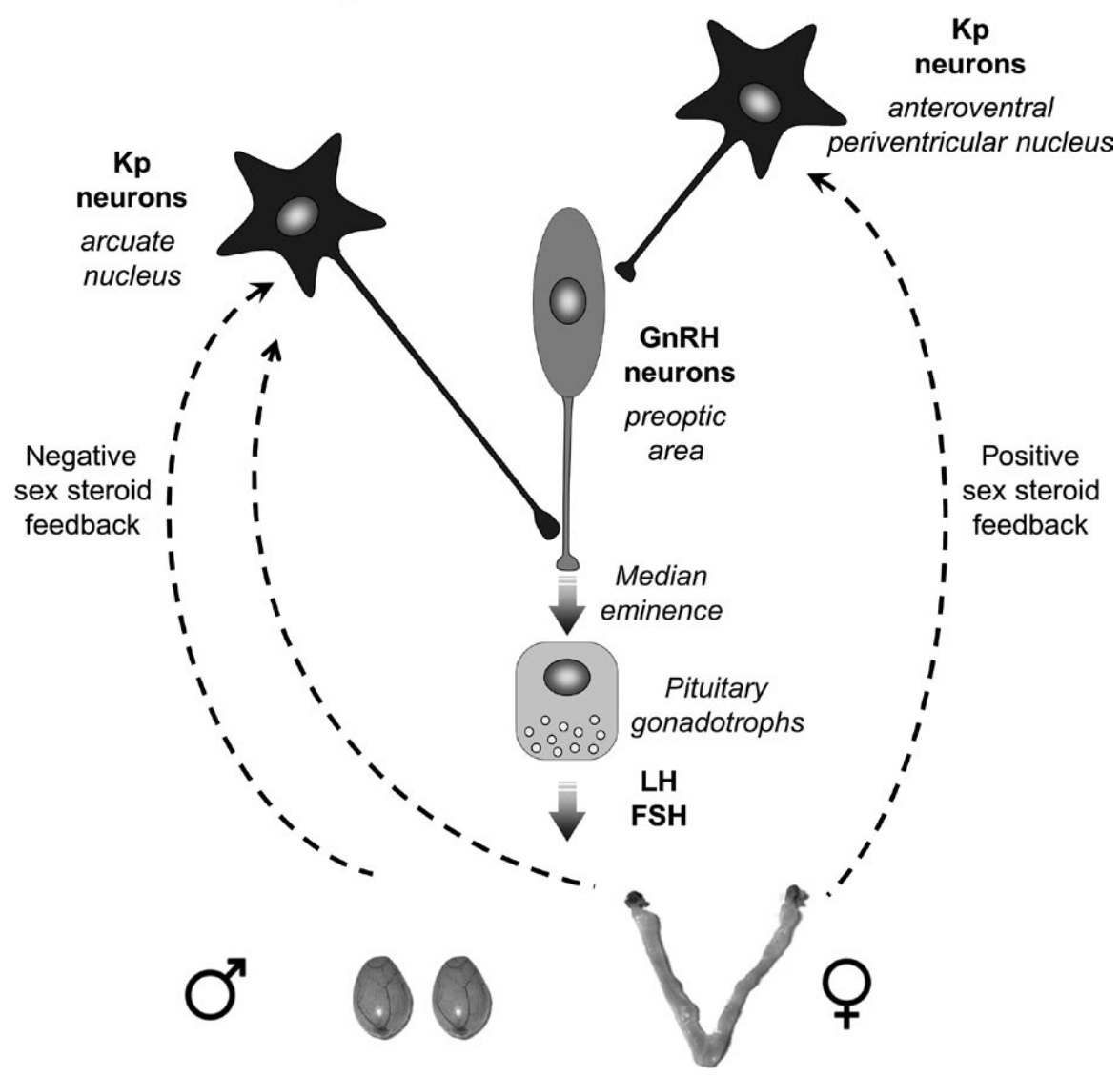

Circadian

input

F IGURE 1 Schematic mammalian hypothalamo-pituitary-gonadal axis including the kisspeptin (Kp) neurons operating upstream of the gonadotropin releasing hormone ( $\mathrm{GnRH})$ neurons which in turn regulate the production of the gonadotropins luteninizing (LH) and folliculo-stimulating (FSH) hormones. $\mathrm{Kp}$ neuron activity is regulated by the sex steroid feedback and by seasonal and circadian inputs et al., 2003; Seminara et al., 2003; Pinilla, Aguilar, Dieguez, Millar, \& Tena-Sempere, 2012 for review) has helped to reassess the mechanisms by which the reproductive system integrates and adapts to daily and seasonal signals.

\section{$2 \mid$ KISSPEPTIN IS A MAJOR PLAYER IN MAMMALIAN REPRODUCTION}

\section{1 | Functional anatomy of the hypothalamo-pituitary-gonadal axis}

Mammalian reproduction relies mainly on tight hypothalamic control of pituitary-driven gonadal activity (Figure 1). Thus, gonadal function is ultimately controlled by a set of neurons located in the hypothalamus and producing GnRH. These neurons are scattered in the preoptic area (POA) and the vascular organ of the lamina terminalis, but also into the mediobasal hypothalamus of nonrodent species, and they mostly project to the median eminence where they release
GnRH into the portal blood in a pulsatile manner (Herbison, 2015 for review). The pattern of GnRH release drives the secretion of the anterior pituitary gonadotropins, folliclestimulating (FSH) and luteinizing ( $\mathrm{LH})$ hormones, which themselves regulate gameto- and steroido-genesis in the gonads. Sex steroids produced by the gonads feedback on the hypothalamo-pituitary axis in order to exert a retrocontrol of reproductive activity. In males, testosterone exerts a sustained negative feedback whereas in females, the feedback is more complex, as estradiol (E2) exerts positive or negative feedback according to the stage of the ovarian cycle and the concentration of circulating E2. Thus, during the first part of the female reproductive cycle, the low level of circulating E2 induces a negative feedback, whereas upon oocyte maturation, the higher secretion of E2 exerts a positive feedback, causing a large release of $\mathrm{GnRH}$ in the hypophyseal portal blood which in turn induces a marked surge of LH triggering ovulation (Christian \& Moenter, 2010 for review). GnRH neurons, however, do not appear to be the direct site of the E2 feedback as they express no E2 receptors Ero and low levels 
of ER $\beta$ (Herbison \& Theodosis, 1992; Hrabovszky et al., 2000), and mice bearing a GnRH neuron-selective deletion of ER $\beta$ exhibit an expected negative feedback and normal cycles (Cheong, Porteous, Chambon, Ábrahám, \& Herbison, 2014). Notably, a study using a GnRH neuron-specific tracing approach showed that E2 acts upon ER $\alpha$-expressing neurons located within rostral periventricular regions of the hypothalamus and projecting onto GnRH neurons (Wintermantel et al., 2006).

This early description of the mammalian hypothalamo-pituitary-gonadal axis left a number of open questions, notably regarding the upstream mechanisms allowing the scattered GnRH neurons to exhibit coordinated pulsatile or surge activity, the cellular targets of the sex steroid feedback, and finally the mechanism by which this functional axis adapts to environmental challenges, particularly daily and seasonal rhythms. Parts of these questions have been answered with the discovery that the neuropeptide $\mathrm{Kp}$, operating upstream of the GnRH neurons, plays a pivotal role in mammalian reproduction (Figure 1).

\section{2 | Discovery of the pivotal role of kisspeptin in mammalian reproduction}

Various (neuro)transmitters had been proposed to regulate $\mathrm{GnRH}$ neuronal activity until the neuropeptide Kp was discovered as a highly potent activator of GnRH release. In 1996, the Kiss 1 gene was first discovered and reported to encode a peptide called metastin because of its antimetastatic property on malignant melanoma cells (Lee et al., 1996). However, in 2003, the receptor of this peptide, Kiss1R (previously named GPR54) was revealed to play a critical role in reproductive physiology by two seminal studies reporting that idiopathic hypogonadotropic hypogonadism in humans is associated with mutation of the Kiss $1 R$ gene (de Roux et al., 2003) and that a targeted deletion of the gene encoding this receptor prevented puberty onset in mice (Seminara et al., 2003). The discovery of this critical role of Kp/Kiss1R signaling in reproductive function has been a milestone in the field of reproductive biology, and numerous studies now indicate that $\mathrm{Kp}$ is required for sexual differentiation and maturation as well as for normal adult reproductive activity in many mammalian species, including humans (Pinilla et al., 2012 for review).

The Kiss 1 gene encodes a family of peptides from an initial 145 amino acid propeptide which is cleaved into peptides of different sizes, from 54 to 10 amino acids characterized by the same $\mathrm{C}$ amidated amino acid terminus (YNWNSFGLRF/Ya), with all forms of Kp binding with a similar high affinity and selectivity to its unique Kiss1R. In mammals, including human, Kissl expressing neurons are found in discrete hypothalamic nuclei: the arcuate nucleus (ARC) and more rostrally either in the anteroventral periventricular area around the 3 rd ventricle (AVPV) in rodents or the POA in nonrodent mammals (Cravo et al., 2011; Franceschini et al., 2006; Gottsch et al., 2004; Hrabovszky et al., 2010; Smith, Clay, Caraty, \& Clarke, 2007; Smith, Cunningham, Rissman, Clifton, \& Steiner, 2005; Smith, Dungan, et al., 2005) (Figure 1). Neuroanatomical connections between the distinct $\mathrm{Kp}$ populations and $\mathrm{GnRH}$ neurons are complex. In rodents, studies indicate that ARC Kp fibers generally contact $\mathrm{GnRH}$ nerve endings and preoptic Kp fibers contact GnRH cell bodies (Yeo \& Herbison, 2011; Yip, Boehm, Herbison, \& Campbell, 2015), whereas in sheep and primates Kp fibers mostly contact GnRH cell bodies (Goodman \& Lehman, 2012 for review). Kp expression in the AVPV/POA is sexually dimorphic with higher expression in females than in males, whereas in the ARC sexual dimorphism appears to depend on species, being observed in sheep but not in rodents (Adachi et al., 2007; Ansel et al., 2010; Cheng, Coolen, Padmanabhan, Goodman, \& Lehman, 2010; Clarkson \& Herbison, 2006; Kauffman et al., 2007). In the ARC, Kp neurons also express neurokininB and dynorphin which act as stimulatory and inhibitory inputs, respectively, onto Kp neurons, and consequently these ARC KNDy neurons are now believed to drive GnRH neuron pulsatility (Choe et al., 2013; Clarkson et al., 2017; Navarro et al., 2009, 2011). Few Kp neurons are also found in extra-hypothalamic areas, notably the medial amygdala, but their role in these brain areas is still not fully understood.

Gonadotropin releasing hormone neurons express Kiss1R (Herbison, d'Anglemont de Tassigny, Doran, \& Colledge, 2010; Irwig et al., 2004; Messager et al., 2005) and in vitro application of 10-100 nM Kp activates nearly all GnRH neurons (Han et al., 2005). Consequently, intracerebroventricaular administration of doses of $\mathrm{Kp}$ as low as 0.1 pmole induces GnRH release (Messager et al., 2005; Plant, Ramaswamy, \& Dipietro, 2006), LH and FSH secretion, and sex steroid production in all mammalian species investigated so far (Gottsch et al., 2004; Irwig et al., 2004; Kinoshita et al., 2005; Navarro et al., 2004; Plant et al., 2006) including man and woman (Dhillo et al., 2005, 2007). Furthermore, specific deletion of Kiss1R in GnRH neurons impairs mouse fertility which can be restored by rescuing the receptor in GnRH neurons (Kirilov et al., 2013; León et al., 2016). The coordinated release of GnRH and LH occurs in a pulsatile manner, a way to avoid receptor desensitization, but additionally in females they are released as a surge to trigger ovulation at the end of the follicular/proestrus phase. Experiments performed in various mammalian species now indicate that ARC Kp (KNDy) neurons form the GnRH pulse generator in males and females (Choe et al., 2013; Clarkson et al., 2017; Han, McLennan, Czieselsky, \& Herbison, 2015; Kanasaki et al., 2017), whereas specifically in females AVPV/POA Kp neurons are responsible for the preovulatory GnRH/LH surge (Caraty, Franceschini, \& Hoffman, 2010; Kinoshita et al., 2005; Smith, Popa, Clifton, Hoffman, \& Steiner, 2006; 
Watanabe et al., 2014). Thus, present studies have demonstrated that reproductive activity in mammals requires $\mathrm{Kp} \mathrm{ac}-$ tion at the Kiss1R on GnRH neurons. Yet, neuroanatomical investigations report that $\mathrm{Kp}$ fiber projections and Kiss1R are also present in other hypothalamic and extra-hypothalamic areas highlighting the complexity of the Kp neuronal system.

One striking feature of Kp neurons is that, in contrast with GnRH neurons, they express a high density of E2 receptors, notably ER $\alpha$ (Adachi et al., 2007; Clarkson, d'Anglemont de Tassigny, Moreno, Colledge, \& Herbison, 2008; Franceschini et al., 2006; Smith, Cunningham, et al., 2005; Smith, Dungan, et al., 2005). Furthermore, the E2 feedback depends on Kp neuron localization as E2 stimulates Kiss1 expression in the AVPV/POA while it inhibits Kiss 1 expression in the ARC in all mammals investigated (Adachi et al., 2007; Ansel et al., 2010; Gottsch et al., 2009; Smith, Cunningham, et al., 2005; Smith, Dungan, et al., 2005) (Figure 1). In nonrodent species, particularly sheep and primates, however, there is evidence that E2 can also stimulate a subset of caudal ARC $\mathrm{Kp}$ neurons during the preovulatory period (Estrada, Clay, Pompolo, Smith, \& Clarke, 2006; Smith, Shahab, Pereira, Pau, \& Clarke, 2010). Notably, mice lacking ER $\alpha$ specifically in Kp neurons display an advanced puberty and extremely irregular estrous cycles, further demonstrating the role of Kp neurons in conveying the E2 feedback toward the GnRH neurons (Greenwald-Yarnell et al., 2016; Mayer et al., 2010). In rodents, it has been proposed that AVPV Kissl activation requires an estrogen response element (ERE)-dependent pathway, whereas inhibition of Kiss 1 expression in the ARC involves ERE-independent mechanisms (Gottsch et al., 2009; Huijbregts \& de Roux, 2010). Furthermore, specifically in the AVPV neurons, E2 increases Kiss1 expression through histone acetylation in the Kiss 1 promoter region (Tomikawa et al., 2012). Altogether, AVPV/POA and ARC Kp neurons are now considered as pivotal nodes for positive and negative E2 feedbacks respectively.

Although $\mathrm{Kp}$ is now considered as indispensable for the activation of GnRH neurons, other neurotransmitters and hormones have been reported to regulate GnRH neuron activity, albeit to a lesser extent, notably GABA, glutamate, neuropeptide $Y$, vasoactive intestinal peptide (VIP), and nitric oxide. GABA is coexpressed in AVPV Kp neurons and a recent study indicates that both transmitters activate $\mathrm{GnRH}$ neurons in a different frequency- and time-dependent manner, yet with Kp remaining dominant at the time of the $\mathrm{LH}$ surge (Piet et al., 2018). In addition, another neuropeptide belonging to the same RF-amide peptide family as Kp, RFRP-3 (the mammalian ortholog of avian gonadotropin inhibitory hormone), deserves a special mention as it also regulates reproductive activity (Henningsen, Gauer, \& Simonneaux, 2016; Kriegsfeld, Jennings, Bentley, \& Tsutsui, 2018; León \& Tena-Sempere, 2015; León et al., 2014; for reviews). RFRP-3 is expressed in neurons exclusively located in the dorsomedial hypothalamus (DMH) and projecting to various brain areas (notably the POA) where fibers make contact with GnRH and Kp neurons; electrophysiological investigations report a direct effect of RFRP-3 on GnRH neuronal firing rate. Unlike Kp however, RFRP-3 inhibits reproductive activity in females, but its effect varies according to species, sex, and environmental conditions.

\section{3 | ROLE OF KISSPEPTIN IN THE FEMALE REPRODUCTIVE CYCLE}

\section{1 | Female reproduction: The ovarian cycle and daily rhythmicity}

In spontaneously ovulating mammalian species, females undergo regular ovarian cycles lasting from a few days (estrous cycle in rodents) to a few weeks (menstrual cycle in women). During the first part of the ovarian cycle (metestrus-diestrus in rodents, follicular phase in women), gonadotrophs produce more FSH than LH and this relative FSH preponderance contributes to the recruitment and development of ovarian follicles leading to a progressive increase in E2 secretion and higher LH receptor expression in granulosa cells (Hillier, 1994 for review). During this early phase, LH pulses occur with a high frequency (period of $20 \mathrm{~min}$ in rodents, 1-2 hr in women) and uniform amplitude. At follicular maturity (proestrus/estrus in rodents, luteal phase in women), the high circulating level of E2 exerts a positive feedback that leads to a marked and transient increase in GnRH and LH secretion, and this GnRH/LH surge (taking place approximately every $4-5$ days in rodents, every 28 days in women) in turn triggers ovulation (occurring in the next few hours in rodents, in $24-48 \mathrm{hr}$ in women) (Levine, 2015; Zeleznik \& Plant, 2015 for reviews). The timing of the preovulatory $\mathrm{GnRH} / \mathrm{LH}$ surge is gated to a specific time of the day, being initiated at the end of the resting period, thus in late afternoon in nocturnal rodents (Legan \& Karsch, 1975; Moline, Albers, Todd, \& Moore-Ede, 1981; Norman, Blake, \& Sawyer, 1973) (Figure 2) and end of the night in diurnal rodents (McElhinny, Sisk, Holekamp, \& Smale, 1999) and women (Cahill, Wardle, Harlow, \& Hull, 1998; Kerdelhué et al., 2002). Furthermore, the occurrence of this daily preovulatory LH surge requires a critical threshold of E2 produced by the developing ovarian follicles. Thus, in ovariectomized mice, the circulating level of E2 is very low and prevents the LH surge from occurring; in contrast, if ovariectomized mice have received an E2 implant, the circulating level of E2 is constantly elevated and this allows the LH surge to occur every day at the light/dark transition (Christian, Mobley, \& Moenter, 2005). This dual, hormonal and circadian, control of the LH surge timing is thought to insure that mating occurs at oocyte maturation and at a time of maximal arousal and activity. 
Day of proestrus

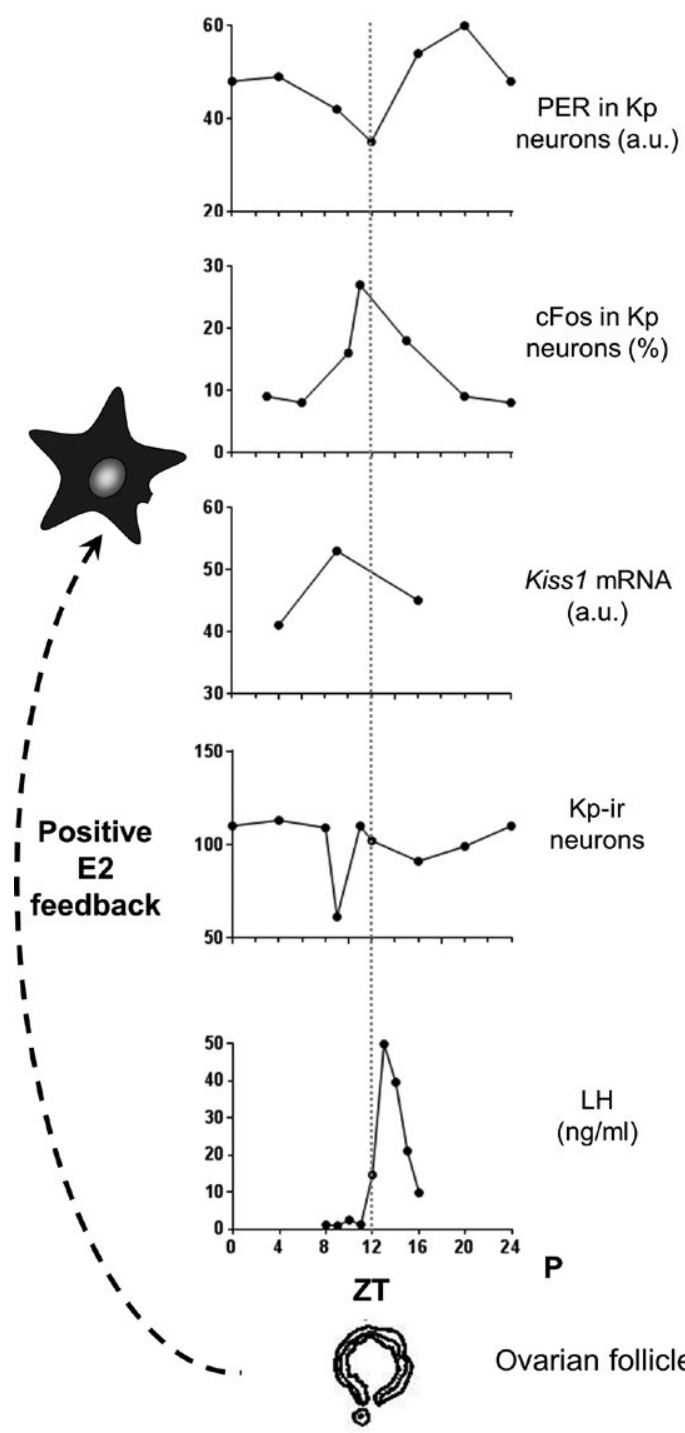

Day of diestrus
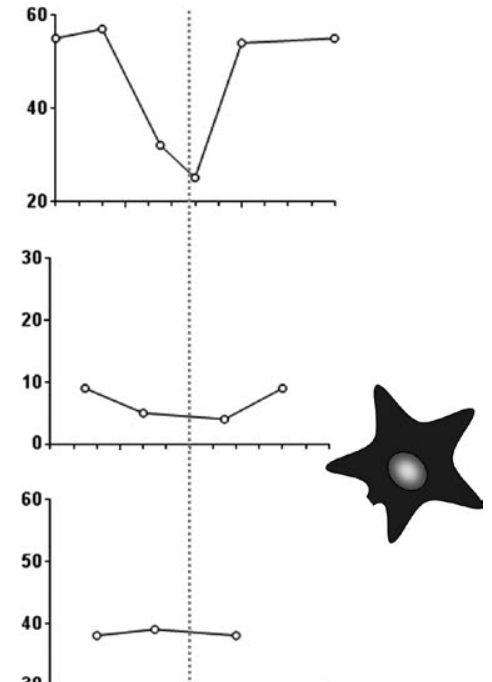

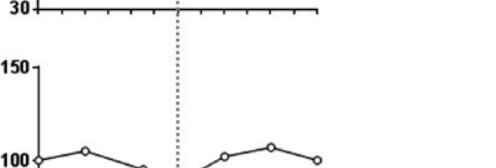

F I G URE 2 Daily rhythm in various cellular activities of the kisspeptin (Kp) neurons of the anteroventral periventricular area (intensity of immunoreactive PER labeling in Kp neurons; percentage of Kp neurons expressing immunoreactive c-FOS; intensity of in situ hybridization signal for Kiss1 mRNA per neurons; number of immunoreactive Kp neurons) and circulating luteninizing hormone (LH) on the day of proestrous (with high circulating estradiol (E2) exerting a positive feedback on Kp neurons) or the day of diestrus (with low circulating E2) in a female nocturnal rodent. The dotted line represents lights off at ZT (zietgeber) 12; a.u. is arbitrarty unit. Adapted from Chassard et al. (2015), Henningsen et al.

(2017); Simonneaux, Bahougne, \& Angelopoulou (2017)

\section{2 | The activity of the suprachiasmatic clock is required for female reproduction}

Daily functions in mammals mostly depend on the activity of a master biological clock located in the hypothalamic suprachiasmatic nuclei (SCN) (Ralph, Foster, Davis, \& Menaker, 1990). The circadian activity of SCN neurons relies on a complex molecular system cycling endogenously with a period of about one day (circa-dies). This molecular clockwork is composed of transcription-translation loops which are now well-described (Takahashi, 2015). The dimer CLOCK/BMAL1 is central to this oscillating system as it binds to specific E-box response elements to induce the transcription of the clock genes Pers and Crys producing PER/ CRY complexes which inhibit the transcriptional activity of CLOCK/BMAL1. This core system is modulated by secondary loops which strengthen the circadian period. Light, mainly through melanopsin-containing intrinsically photosensitive retinal ganglion cells projecting directly to the $\mathrm{SCN}$, is able to change the phase of the circadian clock, and therefore the daily rhythm in light/dark alternation synchronizes the circadian clock to a precise $24 \mathrm{hr}$-period (Berson, 2002; Hattar, Liao, Takao, Berson, \& Yau, 2002; Ruby, Brennan, et al., 2002). The CLOCK/BMAL1 dimer also activates 
expression of other (clock-controlled) genes which therefore may undergo rhythmic expression. This mechanism was first demonstrated for the gene encoding vasopressin, an important output of the SCN clock (Jin et al., 1999). Consequently, levels of SCN vasopressin mRNA are markedly higher during the day than at night, and in Clock mutated mice the $\mathrm{SCN}$ vasopressin rhythm is strongly dampened (Miller et al., 2006).

Various experiments were performed in rodents to disclose whether functional SCN are required for the female reproductive cycle. Early experiments with SCN lesions (Brown-Grant \& Raisman, 1977) or SCN-POA neuronal connection cuts (Wiegand, Terasawa, Bridson, \& Goy, 1980) resulted in the impairment of the LH surge and estrous cyclicity in female rats. Furthermore, female mice carrying Clock or Bmall mutations display disrupted LH surges and estrous cycles (Dolatshad et al., 2006; van der Horst et al., 1999; Miller et al., 2004; Ratajczak, Boehle, \& Muglia, 2009). Interestingly, the reproductive phenotype of young Clock, Bmall or Per1/Per2 mutated mice resembles that of middle aged wild type mice with increased duration of estrous cycles, thus suggesting that alterations in biological clock functioning may lead to advanced reproductive senescence.

In nonrodent mammals like human, monkey, or sheep, the role of the circadian system in timing reproductive activity is discussed (Plant, 2012; Goodman \& Inskeep, 2014 for reviews). In women, the preovulatory LH surge occurs more frequently in late night/early morning (Kerdelhué et al., 2002) and women with single-nucleotide polymorphisms in Bmall have more miscarriages and altered pregnancies than those without such polymorphisms (Kovanen, Saarikoski, Aromaa, Lönnqvist, \& Partonen, 2010). Yet, another study reported that under controlled constant routine protocol, there is no circadian rhythm of LH and FSH during the early follicular phase despite the presence of endogenous rhythms of core body temperature, suggesting that daily rather than circadian cues control the diurnal rhythms in reproductive-aged women (Klingman, Marsh, Klerman, Anderson, \& Hall, 2011).

Production of the two main SCN neurotransmitters, vasopressin and VIP, varies during the day and peaks around the time the LH surge is generated (Francl, Kaur, \& Glass, 2010; Kalsbeek, Buijs, Engelmann, Wotjak, \& Landgraf, 1995). Early physiological experiments pointed to a functional role of vasopressin in the GnRH/LH surge timing. Thus, inhibition of vasopressin signaling with a V1a antagonist results in a reduction in the estradiol-induced LH surge (Funabashi, Aiba, Sano, Shinohara, \& Kimura, 1999), while intracerebroventricular infusion of vasopressin in SCN lesioned, ovariectomized, and E2 treated rats (Palm, van Der Beek, Wiegant, Buijs, \& Kalsbeek, 1999) or in Clock mutant mice (Miller et al., 2006) is able to rescue an LH surge. On the other hand, blockade of VIP signaling in the POA or in the SCN decreases the amplitude of the LH surge (van der Beek, Swarts,
\& Wiegant, 1999; Harney, Scarbrough, Rosewell, \& Wise, 1996) while central infusion of VIP rescues the LH surge in middle-aged female rats (Sun, Shu, Kyei, \& Neal-Perry, 2012). Yet, in E2 treated cocultures of POA and SCN, the GnRH surge is coordinated with the rhythm in vasopressin, not VIP, and administration of vasopressin, not VIP, on POA explants significantly increased GnRH release (Funabashi, Shinohara, Mitsushima, \& Kimura, 2000). Furthermore, initiation of the LH surge is coupled to increased activity in the dorsal SCN which comprises vasopressin neurons (Smarr, Morris, \& de la Iglesia, 2012). Taken together, these findings, provide evidence for a pivotal role of SCN vasopressin neurons in the timing of the LH surge in female rodents, although a role for VIP and possibly other transmitters cannot be excluded.

\subsection{Kisspeptin is pivotal for the integrationof daily and estradiol cues in the female reproductive axis}

Anterograde tract tracing studies show that a number of vasopressin-containing axons of SCN origin make close appositions to Kp neurons which express V1a receptors, whereas very few or no VIP terminals were found apposed to Kp neurons (Vida et al., 2010; Williams, Jarjisian, Mikkelsen, \& Kriegsfeld, 2011). Notably, the number of vasopressin terminal inputs (Vida et al., 2010) and levels of V1a mRNA (Smarr, Gile, \& de la Iglesia, 2013) in Kp neurons are increased in the presence of E2.

In line with these neuroanatomical observations, exogenous administration of vasopressin is able to induce c-FOS expression in AVPV Kp neurons in vivo (Williams et al., 2011) or to increase the firing rate and intracellular $\mathrm{Ca}^{2+}$ of AVPV Kp neurons in hypothalamic slices (Piet, Fraissenon, Boehm, \& Herbison, 2015), and this stimulatory effect of vasopressin is similar whether applied in morning or afternoon. Notably, the vasopressin-induced activation of Kp neurons is lost in ovariectomized mice and fully restored in E2 treated mice (Piet et al., 2015).

As a consequence of the rhythmic stimulatory SCN vasopressin input (Kalsbeek et al., 1995), endogenous activity of AVPV Kp neurons, assessed by c-FOS expression, is increased at the light/dark transition; this rhythm depends on circulating E2 as it is observed in proestrus or ovarectomized $(\mathrm{OVX})+\mathrm{E} 2$ but not in diestrus or OVX female rodents (Adachi et al., 2007; Henningsen, Ancel, Mikkelsen, Gauer, \& Simonneaux, 2017; Robertson, Clifton, de la Iglesia, Steiner, \& Kauffman, 2009; Smith et al., 2006; Williams et al., 2011) (Figure 2). Furthermore, this E2-dependent daily activation of AVPV Kp neurons is associated with a matching increase in Kiss 1 expression, decrease in Kp immunoreactivity and occurrence of the GnRH/LH surge observed in proestrus or OVX $+\mathrm{E} 2$ but not in diestrus or OVX female 
rodents (Adachi et al., 2007; Chassard, Bur, Poirel, Mendoza, \& Simonneaux, 2015; Robertson et al., 2009; Smarr et al., 2013; Smith et al., 2006) (Figure 2). These data indicating a pivotal role of AVPV Kp neurons in the induction of the LH surge are strengthened by the observation that in Gpr54 and Kiss 1 null mice (Clarkson et al., 2008) or after the application of a Kp antibody (Adachi et al., 2007; Kinoshita et al., 2005) or a Kiss1R antagonist (Roseweir et al., 2009), the preovulatory surge is abolished and the ovarian cycles are impaired. Most of these studies have been performed in female rodents, and whether this is transposable to nonrodent species is still discussed (Beltramo, Dardente, Cayla, \& Caraty, 2014; Goodman \& Inskeep, 2014). Data support a role for POA Kp neurons because they exhibit an increased c-FOS expression at the time of their LH surge in ewe (Hoffman, Le, Franceschini, Caraty, \& Advis, 2011; Merkley et al., 2012) and monkey (Watanabe et al., 2014), and levels of POA Kiss 1 mRNA increase during the follicular phase (Smith, Li, Pereira, \& Clarke, 2009), but other studies also suggest a contribution of the ventromedial hypothalamus/ARC region (Caraty et al., 2010; Merkley et al., 2012; Smith et al., 2009). Overall, these results indicate that Kp neurons located in the
AVPV/POA are activated by a daily signal provided essentially via monosynaptic vasopressin $\mathrm{SCN}$ input, and that the integration of this signal within Kp neurons is gated by high circulating E2 produced by mature oocytes (Figure 3).

This functional pathway is believed to time the GnRH/ LH surge to the beginning of the daily active period of the mature reproductive stage. However, GnRH neurons may receive other neuronal inputs forwarding daily time cues (Figure 3). Thus SCN VIP-expressing neurons are reported to project to GnRH neurons (van der Beek, Wiegant, van der Donk, van den Hurk, \& Buijs, 1993) with females exhibiting higher VIPergic innervation than males in the rat (Horvath, Cela, \& van der Beek, 1998). Furthermore, GnRH neurons express the VIP receptor VPAC2 (Smith, Jennes, \& Wise, 2000) and can be activated by exogenous VIP in hypothalamic slices (Christian \& Moenter, 2008; Piet, Dunckley, Lee, \& Herbison, 2016). Additionally, an increasing number of studies indicate that RFRP-3 neurons may as well participate in the daily gating of the $\mathrm{GnRH} / \mathrm{LH}$ surge in an opposite manner to Kp neurons. Indeed, RFRP-3 neurons project to GnRH neurons to inhibit their neuronal activity and LH secretion, and the RFRP-3 neurons exhibit
F I G U RE 3 Working model illustrating the hypothalamic network involved in the daily gating of the preovulatory surge of luteinizing hormone (LH) in female rodents. Environmental light cues synchronize the daily rhythm in vasopressin and vasoactive intestinal peptide (VIP) release by the suprachiasmatic nuclei (SCN). In the late afternoon, and under the condition of high circulating estradiol (E2) exerting a positive feedback on kisspeptin (Kp) neurons, vasopressin activates $\mathrm{Kp}$ neurons which release the neuropeptide on the gonadotropin releasing hormone $(\mathrm{GnRH})$ neurons which in turn trigger the preovulatory LH surge at the end of the resting period. VIP, but also the (Arg)(Phe) related peptide (RFRP-3) located in the dorsomedial hypothalamus (DMH), directly activates and inhibits, respectively, the GnRH neurons

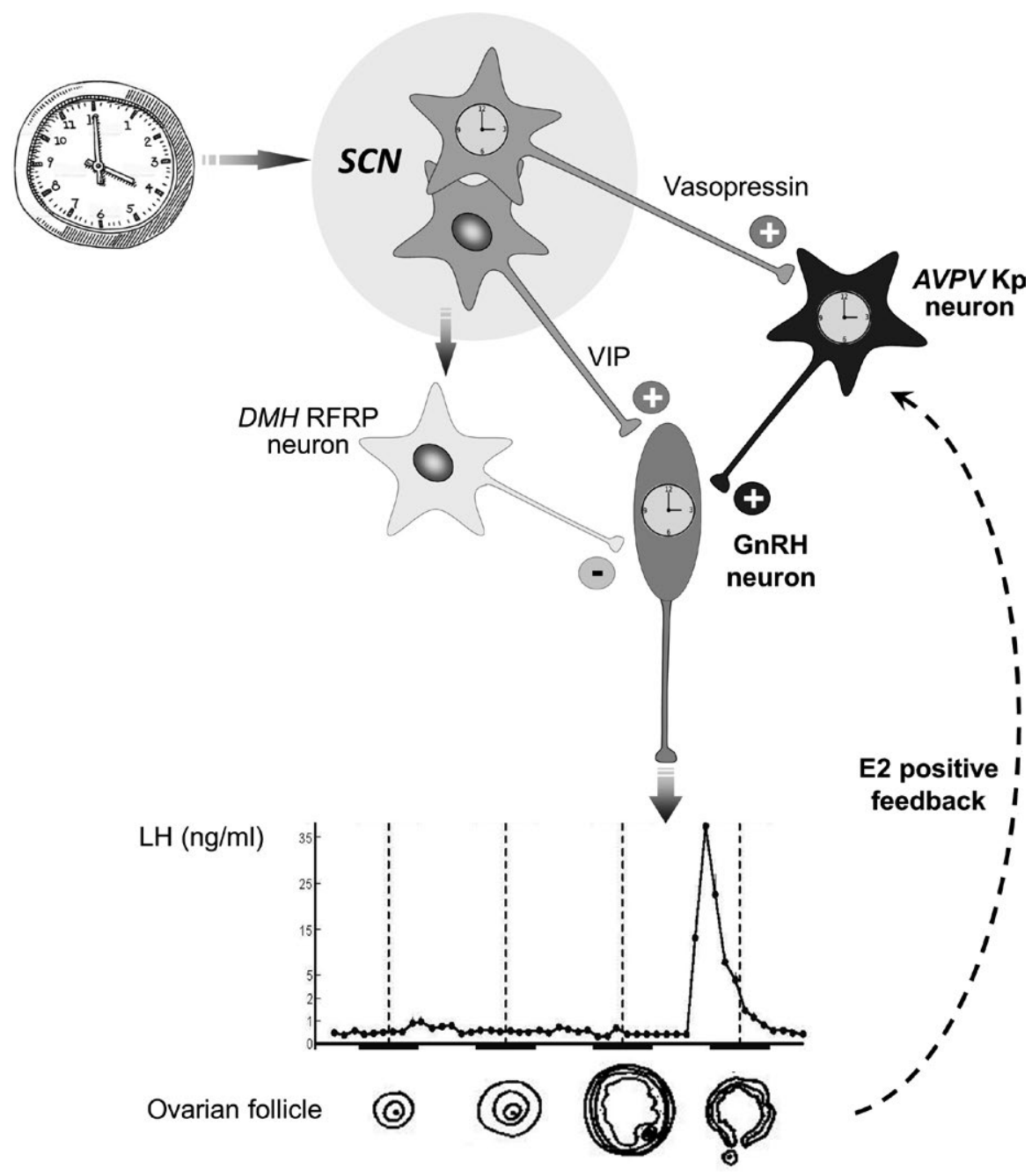


a decreased activity at the light/dark transition possibly under the control of VIP SCN inputs (Gibson et al., 2008; Henningsen et al., 2017; Kriegsfeld et al., 2006; Russo et al., 2015).

\section{4 | Role of secondary reproductive clocks in female reproduction}

Although the master SCN circadian clock is essential in driving biological rhythms, it is now established that secondary clocks located in other central structures and peripheral organs are part of a complex hierarchical multioscillator system (Honma, 2018; Menaker, Murphy, \& Sellix, 2013 for reviews). In this context, the hypothalamo-pituitary-gonadal axis also appears as a functional multioscillatory axis as all reproductive structures from the hypothalamic neurons down to the ovaries and the uterus display endogenous circadian oscillations of clock genes (Sellix, 2013; Simonneaux \& Bahougne, 2015 for reviews).

Thus, virtually all AVPV Kp neurons express the PER1 protein with a daily rhythm (Figure 2) and Kp-expressing AVPV explants isolated from PER2::LUCIFERASE mice display sustained circadian oscillations (Chassard et al., 2015). The daily rhythm of PER1 in Kp neurons is not abolished under low circulating E2 (in diestrus) but the period of the Kp neuronal clock in isolated AVPV explants is lengthened in the presence of E2 in the culture medium (Chassard et al., 2015). The occurrence of a circadian clock has also been suggested in immortalized POA Kp cell lines where E2 induces circadian rhythms in Kiss 1 gene expression (Jacobs, Veitch, \& Chappell, 2016). These data suggest that AVPV Kp neurons host a circadian clock, but its role is yet to be established. It may regulate E2 sensitivity in a time-dependent manner as $E R$ gene expression is regulated by the BMAL1/ CLOCK dimer (Cai et al., 2008) or it may contribute to the rhythm in Kiss 1 expression through the circadian transcriptional factor albumin D-site binding protein (Xu et al., 2011).

Gonadotropin releasing hormone neurons express all core clock genes with an endogenous circadian cycle (Chappell, White, \& Mellon, 2003; Gillespie, Chan, Roy, Cai, \& Belsham, 2003; Hickok \& Tischkau, 2010) and this GnRH clock appears functionally coupled to GnRH secretion and may time GnRH neuronal sensitivity to upstream neural inputs (Chappell et al., 2003; Choe et al., 2013; Mansuy, Risold, Glauser, Fraichard, \& Pralong, 2009; Zhao \& Kriegsfeld, 2009). Notably, the GnRH neurons express a circadian rhythm in Kiss $1 R$ expression (Tonsfeldt, Goodall, Latham, \& Chappell, 2011) and respond to the Kp signal in a time-of-day dependent manner, that is in the afternoon rather than in the morning (Williams et al., 2011). A similar daily gating of VIP activation of GnRH neurons has been suggested but this is still debated (Christian \& Moenter, 2008; Piet et al., 2016; van der Beek, van Oudheusden, Buijs, van der Donk, van den Hurk, \& Wiegant, ). Therefore, the GnRH circadian clock may provide a time-keeping mechanism to appropriately release GnRH following upstream stimulation, notably by $\mathrm{Kp}$.

Gonadotroph alphaT3-1 cells also express all cognate clock genes but female mice bearing gonadotroph-specific Bmall knock-out display a normal preovulatory LH surge and reproductive activity, suggesting that this gonadotrophic clock is dispensable for the LH surge but may yet contribute to estrous cycle robustness (Chu et al., 2013; Resuehr, Wildemann, Sikes, \& Olcese, 2007).

The ovary also hosts intrinsic circadian clocks which appear to have functional relevance (Sellix, 2015 for review). All ovarian cell types host a circadian clock which can be regulated by gonadotropins (Yoshikawa, Sellix, Pezuk, \& Menaker, 2009). Furthermore, genes encoding the LH receptor and steroid hormone biosynthesis enzymes display circadian rhythms which are altered following selective Bmall deletion (Chen et al., 2013). Finally, ovaries display a circadian rhythm in LH-induced ovulation with greater ovulation rates on the night of proestrus, indicating that the ovarian clock may set LH responsiveness to optimize the timing of ovulation (Sellix, Yoshikawa, \& Menaker, 2010).

Therefore, Kp neurons together with GnRH neurons and ovaries appear to form a multioscillatory reproductive axis which may help to time various reproductive functions.

\section{5 | Impact of circadian disruption on female fertility}

Early studies indicate that in women the LH surge also occurs at the end of the resting period (Cahill et al., 1998; Kerdelhué et al., 2002; Seibel, Shine, Smith, \& Taymor, 1982), suggesting that at least part of the regulatory mechanisms reported in animal models may drive the timing of human ovulation. In this context, it is important to consider that an increasing number of women are living in a disrupted daily environment, notably those working in the so called shift work condition (up to $20 \%$ of women in industrialized countries). It is likely that such environmental circadian disruption can impair the robustness and efficiency of reproductive cycles in women. Actually, epidemiological studies report that shift work is not only associated with an increased risk of developing cardiovascular and metabolic disorders, and some types of cancer, but also with reproductive alterations such as higher rates of short menstrual cycles, higher levels of circulating E2, increased prevalence of menstrual disorders, and longer delay to pregnancy (Matheson, O'Brien, \& Reid, 2014; Simonneaux \& Bahougne, 2015; Simonneaux, et al., 2017 for reviews).

Shift work is a very complex situation, often associated with potential confounding factors (diet, social stress, sleep 
disturbance, use of psychostimulants), and therefore it is difficult to design appropriate animal model conditions that truly mimic human shift work. An early in vitro study reported that in PER2::LUCIFERASE mice submitted to a $6 \mathrm{hr}$ phase advance, the ovarian clock was not fully resynchronized 6 days after the shift (Yoshikawa et al., 2009). Recently, an in vivo experiment showed that female mice submitted to a single $10 \mathrm{hr}$-phase advance exhibit a shifted (2-3 hr delayed) LH surge associated with longer and irregular estrus cycles during the next two reproductive cycles (Simonneaux et al., 2017).

While a number of studies have now described in detail how daily environmental cues and intrinsic circadian clocks drive female reproductive cycles, only a few experiments have investigated the effect of daily/circadian disruption on female reproduction. The few available data suggest that a single phase shift can alter the timing of the LH surge, the length of the estrous cycles, and the internal synchronization of peripheral reproductive clocks. Thus, clearly more studies, notably in diurnal species, are now required to investigate how chronic shifts, as experienced by an increasing number of women in shiftwork conditions, can impact female reproductive cycles and fertility.

\section{6 $\quad$ Concluding remarks on the role of kisspeptin in mediating daily cues to the hypothalamo-pituitary-gonadal axis}

The daily and estrogenic regulation of female reproduction is pivotal to allow the timing of ovulation to coincide with optimal reproductive tract functioning, maximal arousal, and sexual motivation, and the best environmental conditions in order to insure reproductive success. Data gathered in the last 15 years have highlighted the fundamental role of preoptic Kp neurons in integrating both daily and estrogenic inputs to time the GnRH/LH surge at the right time of the day of the right reproductive stage. Actually, current data now suggest that the occurrence of the preovulatory GnRH/LH surge may depend on a complex network involving (a) an E2-dependent SCN- driven vasopressin activation of preoptic Kp neurons at the end of the resting period, (b) a time-of-day dependent Kp activation of GnRH neurons, (c) a SCN-driven VIP activation of GnRH neurons, (d) a reduction in the RFRP-3 tonic inhibition of GnRH neurons at the end of the resting period, and (e) peripheral reproductive clocks which may time cell sensitivity to the regulatory inputs (Figure 3). During acute and chronic environmental shifts, this delicate timing of the reproductive network is likely to be disrupted. Therefore, more studies should investigate the impact of circadian disruption on the reproductive cycle and fertility in women and in animal models of shift work.
4 ROLE OF KISSPEPTIN IN MAMMALIAN SEASONAL REPRODUCTION

\section{1 | Annual rhythms of reproduction in mammals}

Animals living in temperate and boreal latitudes experience marked seasonal changes in their environment. To overcome these environmental challenges, thus increasing their chances of survival, they display seasonal changes in several aspects of their physiology, such as reproduction, metabolism, and behavior. Thus, reproductive activity is restricted to a particular time of year so that birth occurs when warmer temperatures and better accessibility to food increase the survival rate of the offspring. Notably, the period of breeding depends on the reproductive physiology so that whatever the duration of gestation, the birth and weaning of the offspring occur in spring and summer. As a consequence seasonal mammals are described as long day (LD) breeders when they mate during increasing day lengths (this is the case of small mammals like hamsters), or short day (SD) breeders when they mate during decreasing day lengths (this is the case of large mammals like sheep). Seasonal reproduction depends on the annual change in photoperiod, but other environmental factors, particularly temperature and food availability, may also play a role. Furthermore, in some species, seasonal physiology is also driven by endogenous long-term mechanisms (circannual clock or photo-refractoriness) which help to anticipate the forthcoming season. Whatever the seasonal mechanisms involved, the photoperiodic change in circulating levels of the pineal hormone melatonin has long been known to be a reliable endocrine calendar for synchronizing reproduction with the seasons (Dardente, 2012; Hazlerigg \& Simonneaux, 2015; Karsch et al., 1984; Reiter, 1993 for reviews).

\section{2 | Role of melatonin in synchronizing reproduction with the seasons}

Photic information reaches the pineal gland via the retino-hypothalamo-pineal pathway that during nighttime generates a release of norepinephrine, a potent stimulator of melatonin synthesis and release from the pineal gland (Simonneaux \& Ribelayga, 2003 for review). As a consequence, the duration of elevated circulating melatonin at night depends on night length with longer melatonin production in SD as compared to LD conditions. Timed melatonin-infusion experiments have established that duration of circulating melatonin rather than its concentration is the key parameter that triggers the photoperiodic response in all seasonal species, thus implying that the photoperiodic change in nocturnal melatonin has an opposite effect on LD and SD breeders (Bartness et al., 1993 for review). This conserved effect of melatonin in relaying 
seasonal cues yet with an opposite reproductive effect on LD and SD breeders is still a mystery, although recent findings on the melatonin site of action and downstream effect within the reproductive hypothalamus has improved our understanding of the neuroendocrine mechanisms by which melatonin synchronizes mammalian reproduction.

Early experiments, using the highly specific 2-[125I]-iodomelatonin, reported high affinity melatonin binding sites in various hypothalamic nuclei and in the pars tuberalis (PT), the rostral part of the adenohypophysis extending along the ventral aspect of the median eminence, which exhibits by far the highest binding density (Vaněcek, Pavlík, \& Illnerová, 1987). Cloning of mammalian melatonin receptors further revealed that there are two high-affinity melatonin receptors, MT1 and MT2, of which the MT1 subtype appears necessary and sufficient for mediating the photoperiodic effect of melatonin (Reppert, Weaver, \& Ebisawa, 1994; Reppert et al., 1995; Weaver, Liu, \& Reppert, 1996; Yasuo, Yoshimura, Ebihara, \& Korf, 2009). Although earlier studies suggested that melatonin can directly target hypothalamic sites, notably the DMH in Syrian hamster (Maywood, Bittman, \& Hastings, 1996), the SCN in Djungarian hamster (Bartness, Goldman, \& Bittman, 1991), and the premammilary region of the hypothalamus in sheep (Malpaux, Daveau, MauriceMandon, Duarte, \& Chemineau, 1998), it has not been possible to determine whether and how melatonin might drive seasonal reproduction through these hypothalamic sites. By contrast, accumulating evidence now points toward the PT as the major site for the integration of the melatonin signal in seasonal breeders (Dardente, Hazlerigg, \& Ebling, 2014; Hazlerigg \& Simonneaux, 2015 for reviews). Thus, most PT cells are thyrotropes which coexpress MT1 and thyroid stimulating hormone (TSH), and expression of $T S H \beta$ is markedly inhibited by the long SD peak of melatonin (Dardente et al., 2010; Klosen et al., 2002; Wittkowski, Bergmann, Hoffmann, \& Pera, 1988).

The thyroid hormones triiodothyronine (T3) and thyroxine (T4) have long been known to be critical for the seasonal regulation of biological functions, notably reproduction, in birds and mammals (Nicholls, Follett, Goldsmith, \& Pearson, 1988 for review), but it is from 2003 that a link between PT TSH and the seasonal role of T3 was discovered (Dardente et al., 2014; Nakane \& Yoshimura, 2014; Yoshimura, 2013 for reviews). Thus, in a pioneering study in quail, Yoshimura et al. (2003) showed that genes encoding enzymes involved in thyroid hormone metabolism, deiodinases type 2 (Dio2, which converts the inactive T4 into bioactive T3) and type 3 (Dio3, which inactivates T4 and T3), are expressed by tanycytes of the third ventricle with an opposite photoperiodic regulation. Dio2 expression is higher and Dio3 expression is lower in LD than in SD, leading to elevated level of T3 in the mediobasal hypothalamus of LD animals. Moreover, these authors showed that T3 microimplants placed in SD-adapted quail were able to rescue a LP reproductive phenotype. Further studies demonstrated that the photoperiodic increase in Dio 2 and decrease in Dio 3 are driven by TSH produced by the PT and acting on TSH receptors located on tanycytes (Hanon et al., 2008; Nakao et al., 2008). Since then, a similar photoperiodic switch in tanycytic Dio2/Dio3, driven by melatonin, has been reported in various seasonal mammals (Barrett et al., 2007; Hanon et al., 2010; Król et al., 2012; Revel, Saboureau, Pévet, Mikkelsen, \& Simonneaux, 2006; Sáenz de Miera et al., 2013, 2014; Watanabe et al., 2004). Furthermore, the capacity of the intrahypothalamic TSH/T3 signal to restore a LD seasonal phenotype (or block a SD phenotype) was confirmed in sheep (Anderson et al., 2003) and Syrian and Djungarian hamsters (Barrett et al., 2007; Klosen, Sebert, Rasri, Laran-Chich, \& Simonneaux, 2013; Murphy et al., 2012).

Altogether these studies have unveiled a functional link between the melatonin-driven TSH release from the PT and the seasonal changes in T3 within the mediobasal hypothalamus. Importantly, this photoperiodic regulation is highly conserved among all seasonal mammals investigated so far, whether they are LD or SD breeders, thus indicating that pathways downstream of T3 adapt the photoperiodic response to the reproductive physiology. Of note however, melatonin producing species like rats or CBA mice, although not seasonal breeders, have retained the capacity to display photoperiodic changes PT TSH and tanycytic Dio2/Dio3 but not gonadal activity (Ono et al., 2008; Ross, Helfer, Russell, Darras, \& Morgan, 2011), indicating that in these species, the TSH-Dio2/3 pathway is functional but disconnected from the downstream reproductive axis.

Despite the marked decrease in GnRH release during sexual quiescence most seasonal species display an unchanged number of GnRH neurons and level of GnRH-immunoreactivity in different photoperiods (Barrell, Moenter, Caraty, \& Karsch, 1992; Urbanski, Doan, \& Pierce, 1991) indicating that GnRH synthesis and release are regulated by upstream signals. Recent studies investigating the mechanisms by which seasonal changes in hypothalamic T3 control reproduction suggest that $\mathrm{Kp}$ may be a functional link between TSH/T3 signaling and the seasonal control of GnRH neuronal activity.

\section{3 | Seasonal variations in kisspeptin are pivotal for annual breeding}

The discovery of the potent stimulatory effect of Kp on the GnRH-dependent regulation of gonadotropin and gonadal activity prompted research on the putative role of this peptide in seasonal reproduction. The first studies performed on male Syrian hamster (Revel, Saboureau, Masson-Pévet, et al., 2006) and ewe (Smith et al., 2007) reported a clear photoperiodic/seasonal variation in Kiss 1 expression in the 


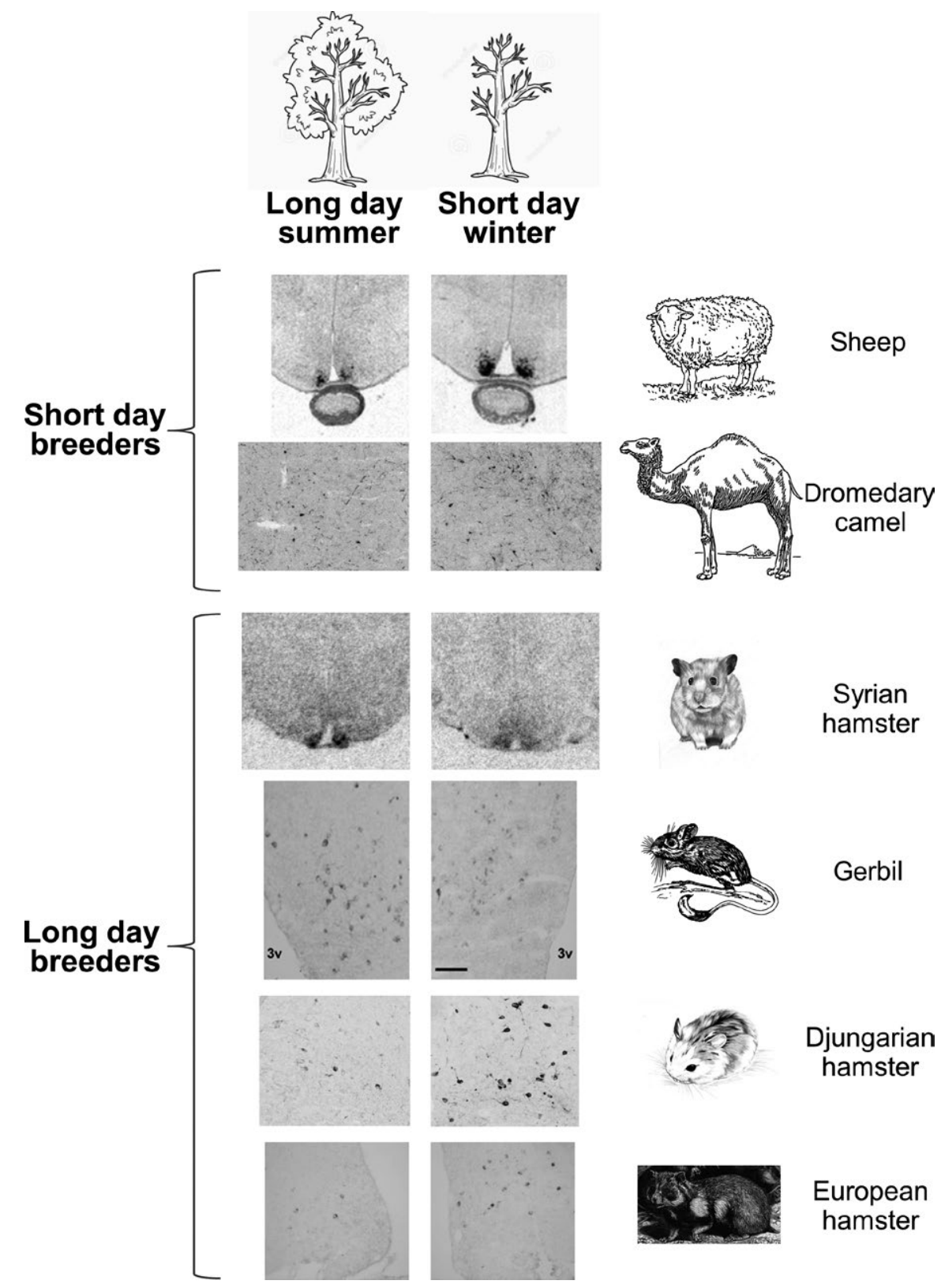

F I G U R E 4 Seasonal/photoperiodic variation in kisspeptin expression in the arcuate nuclei of various short day or long day breeders. Adapted from Lomet et al. (2018) for the sheep; Ainani et al. (2018) for the dromedary; Revel, Saboureau, Masson-Pévet, et al. (2006); for the Syrian hamster; Talbi et al. (2016) for the jerboa; Rasri-Klosen et al. (2017) for the Djungarian hamster; Sáenz de Miera et al. (2014); for the European hamster

ARC of both species with higher values associated with the breeding season, that is during LD for the Syrian hamster and during SD for the ewe (Figure 4). In sheep, it was shown that the increased $\mathrm{Kp}$ expression in the breeding season is associated with a greater number of Kp terminal contacts onto GnRH neurons compared to the nonbreeding season (Smith et al., 2008). Because seasonal changes in circulating sex steroids might be responsible for such variation, castration with/without hormonal replacement was performed and these experiments confirmed the inhibitory effect of sex steroids on ARC Kissl mRNA, as already reported in nonseasonal species (Revel, Saboureau, Masson-Pévet, et al., 2006; Smith et al., 2007). Therefore, the higher expression of ARC Kiss 1 expression in sexually active Syrian hamster and ewe has to be driven by strong seasonal cues able to counteract the negative sex steroid feedback. ARC Kp neurons are known to coexpress neurokininB and dynorphin, and these two peptides in Syrian hamster (Bartzen-Sprauer, Klosen, Ciofi, Mikkelsen, \& Simonneaux, 2014) but only neurokininB in sheep (Weems et al., 2017) also exhibit seasonal changes driven by steroid-dependant and steroid-independent mechanisms. Further studies confirmed the occurrence of seasonal/ photoperiodic variation in ARC Kp expression in a number of seasonal breeders, notably the Djungarian hamster (Greives 
et al., 2007; Rasri-Klosen, Simonneaux, \& Klosen, 2017), European hamster (Sáenz de Miera et al., 2014), Libyan jird (Boufermes et al., 2014), jerboa (Talbi, Klosen, Laran-Chich, El Ouezzani, \& Simonneaux, 2016), red deer (Barrell et al., 2016), and dromedary camel (Ainani et al., 2018) (Figure 4). Surprisingly however, in some species like the Djungarian and European hamsters, ARC Kp expression is lower in sexually active LD-adapted animals, and manipulating circulating sex steroids demonstrated that in these species the stimulatory effect of LD on Kp expression is overridden by a robust negative sex steroid feedback (Greives et al., 2008; Rasri-Klosen et al., 2017; Sáenz de Miera et al., 2014). In the POA, expression of Kp also exhibits seasonal variation, notably in female hamsters and in ewe, but here these variations appear only driven by the positive sex steroid feedback, and not by seasonal cues (Ansel et al., 2010; Chalivoix et al., 2010; Greives et al., 2007; Rasri-Klosen et al., 2017; Sáenz de Miera et al., 2014; Smith et al., 2008).

The relevance of seasonal variation in hypothalamic Kiss 1 expression was challenged by investigating the effect of exogenous Kp administration in photo-inhibited animals. Thus, chronic intracerebroventricular infusion of a low dose of $\mathrm{Kp}$ in SD-adapted, sexually inactive, male Syrian (Revel, Saboureau, Masson-Pévet, et al., 2006), or Djungarian (Rasri-Klosen et al., 2017) hamsters is able to fully rescue testicular activity within 4-5 weeks (both testis weight and testosterone production being similar to LD-adapted hamsters). Repeated peripheral injections of $\mathrm{Kp}$ can also reactivate rodent reproduction with appropriate frequency and forms of Kp (Ansel et al., 2011). Similarly, anestrous ewe, receiving a $48 \mathrm{hr}$ long intravenous infusion of a low dose of $\mathrm{Kp}$, are able to produce surge levels of LH and ovulate as observed at the estrous season (Caraty et al., 2007). Altogether these data demonstrate that seasonal breeders display variations in hypothalamic Kp expression that might help to synchronize reproduction with the time of the year.

\subsection{Melatonin is able to drive seasonal variations in kisspeptin expression}

As it is well-established that photoperiodic changes in circulating melatonin drive seasonal breeding, the effect of pinealectomy and melatonin replacement was tested on Kp expression in the male and female Syrian hamster (Ansel et al., 2010; Revel, Saboureau, Masson-Pévet, et al., 2006). The results clearly demonstrated that the large production of melatonin in SD inhibits ARC Kiss 1 expression, this effect being further modulated by the negative sex steroid feedback, whereas the melatonin-driven change in AVPV Kiss l only depends on the positive sex steroid feedback. A similar inhibitory effect of melatonin on Kp expression was also reported in the Turkish (Piekarski et al., 2014) and striped (Li et al., 2015) hamster and even in the rat (de Oliveira et al., 2018). Although a direct effect of melatonin on Kp expression in a hypothalamic cell line has been reported (Gingerich et al., 2009), in vivo studies have demonstrated that ARC Kp neurons do not express MT1 (Li, Rao, Pereira, Clarke, \& Smith, 2011). Furthermore, because melatonin is now believed to act at the PT to synchronize seasonal functions via local TSH/T3 signaling, it was postulated that this TSH/T3 signal may drive seasonal change in ARC Kp. Actually, a chronic central infusion of TSH in SD-adapted sexually inactive Syrian and Djungarian hamsters is able to rescue a LD-phenotype of ARC Kp expression and testicular activity (Klosen et al., 2013). Furthermore, exogenous T3 administration to SD-adapted Djungarian hamsters also restores the LD phenotype of hypothalamic Kp and gonadal activity (Henson, Carter, \& Freeman, 2013).

At this point, whether and how hypothalamic T3 acts on $\mathrm{ARC} \mathrm{Kp}$ neurons is a matter of debate. Although Kp neurons, as many hypothalamic neurons, express the T3 receptor TR $\alpha$ (Dufourny, Gennetay, Martinet, Lomet, \& Caraty, 2016), studies favor an indirect effect of T3 on Kp expression. The best evidence comes from the observation that a similar high T3 signal (in summer LD) induces an opposite effect on ARC Kp expression in a SD (sheep) and LD (Syrian) breeder. Furthermore, a recent in vitro study failed to demonstrate an effect of T3 on Kp expression in hypothalamic explants (Dufourny et al., 2016).

In all seasonal species investigated so far, whether LD or SD breeders, there is a conserved marked inhibition of RFRP-3 expression driven by the SD pattern of melatonin (Lomet et al., 2018; Revel, Saboureau, Pévet, Simonneaux, \& Mikkelsen, 2008; Smith et al., 2008; Henningsen et al., 2016 for review) and in seasonal rodents, this SD-inhibition is fully rescued by a chronic infusion of TSH (Klosen et al., 2013) or T3 (Henson et al., 2013). Furthermore, a chronic central infusion of RFRP-3 in SD-adapted male or female Syrian hamsters is able to rescue the LD phenotype of ARC $\mathrm{Kp}$ expression and gonadal activity (Ancel et al., 2012; Henningsen et al., 2017). Altogether, these observations indicate that, at least in seasonal rodents, the melatonin-driven TSH/T3 signal may synchronize reproductive activity via a regulation of RFRP-3 synthesis which in turn acts on ARC $\mathrm{Kp}$ and the downstream gonadotropic axis (Figure 5). In sheep, early studies reported an inhibitory effect of RFRP-3 on gonadotropin secretion (Clarke et al., 2008; Sari, Rao, Smith, Tilbrook, \& Clarke, 2009) and this led to the attractive hypothesis that in sheep, unlike in hamsters, the SD pattern of melatonin would activate breeding activity through a decreased inhibitory input of RFRP-3 toward the gonadotropic axis. However, a recent study using various protocols of peptide administration reported that RFRP-3 is unable to inhibit gonadotropin secretion in the sheep (Decourt et al., 2016). Therefore, in the sheep, although there is a clear seasonal variation in Kiss 1 and Rfrp expression (Chalivoix et al., 2010; Lomet et al., 2018; Smith et al., 2007, 2008) the pathway linking seasonal cues to Kp neurons is not yet clearly identified. Of note, the involvement of dopaminergic neurons 


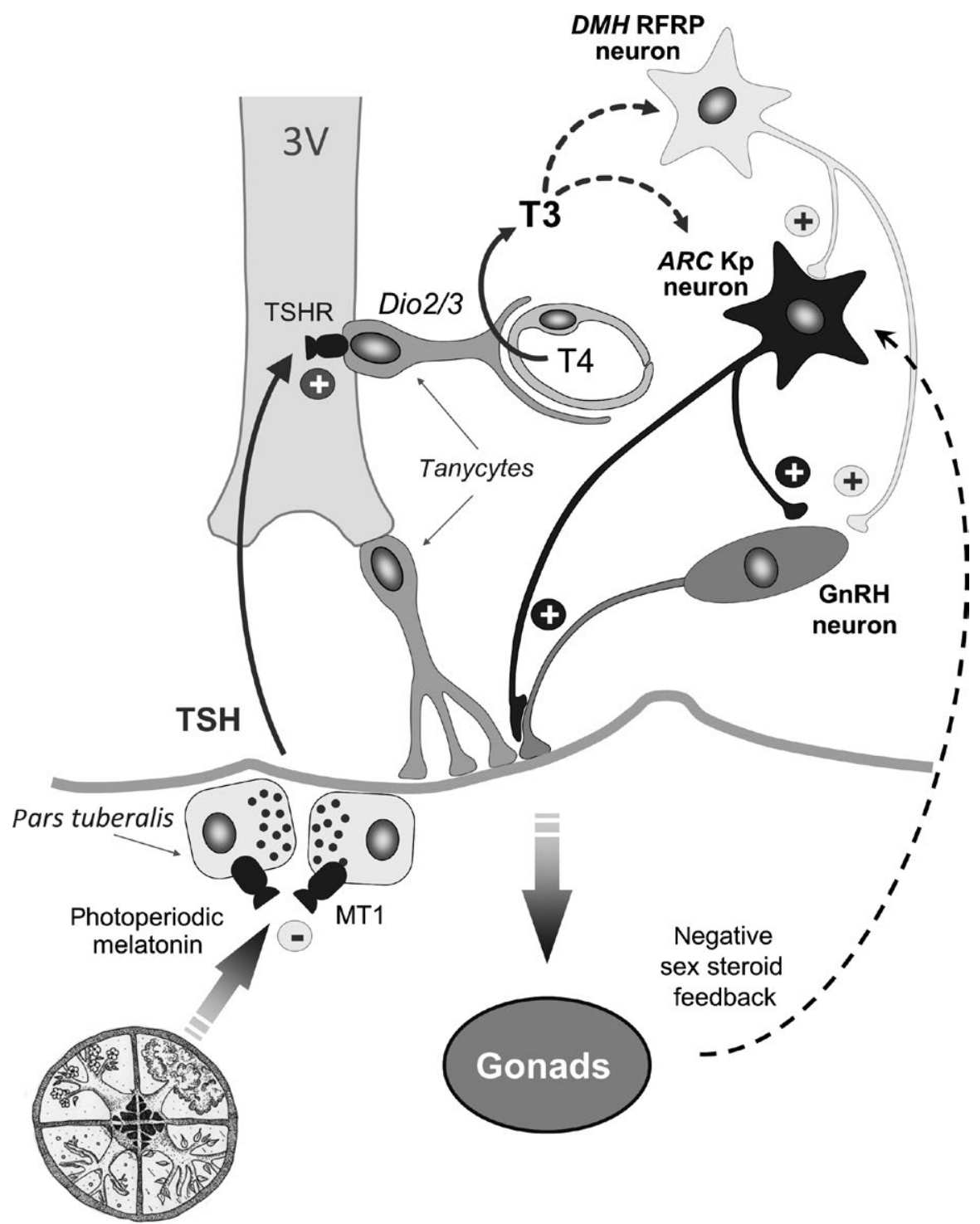

F I G U RE 5 Working model illustrating the hypothalamic network involved in the photoperiodic synchronization of reproduction in seasonal rodents. Melatonin, the nocturnal secretion of which depends on photoperiod, acts at the pars tuberalis of the adenohypophysis to regulate the synthesis of thyroid stimulating hormone (TSH). Under long days, TSH secretion is increased and it binds to its receptor located on tanycytes to regulate the deiodinase (Dio)2/Dio3 balance leading to a higher concentration of thyroid hormone (T3) in the mediobasal hypothalamus. T3 in turn activates arcuate nucleus (ARC) kisspeptin (Kp) neurons via still unknown mechanisms which may involve the (Arg)(Phe)related peptide (RFRP-3) neurons located in the dorsomedial hypothalamus (DMH). The following increase in the gonadotropin releasing hormone (GnRH)-driven gonadotropin secretion promotes gonadal growth and activity. Finally, the increased sex steroid production exerts a negative feedback on the ARC Kp neurons

of the A15 region relaying seasonal cues to Kp and RFRP-3 neurons has recently been proposed (Ciechanowska, Łapot, Paruszewska, Radawiec, \& Przekop, 2017; Goodman et al., 2012; Weems, Goodman, \& Lehman, 2015).

\section{5 | Concluding remarks on the role of kisspeptin in mediating seasonal cues to the hypothalamo-pituitary-gonadal axis}

In all seasonal species investigated so far, hypothalamic Kiss 1 expression displays seasonal variations. In ARC Kp neurons, this variation appears to be driven by seasonal cues and further modulated by the sex steroid feedback, whereas in preoptic Kp neurons it appears mostly to depend on the sex steroid feedback. In both photo-inhibited sheep and hamsters, exogenous Kp infusion is capable of fully rescuing reproductive activity, thus strengthening the physiological relevance of $\mathrm{Kp}$ in the regulation of seasonal breeding. The mechanisms by which seasonal cues regulate Kiss 1 expression, however, are not fully identified. Whether the seasonal change in melatonin-driven hypothalamic T3 is pivotal for regulating ARC Kiss1 expression and the mechanisms involved in this regulation require further investigations. Notably, 
recent studies have demonstrated that melatonin-independent long-term mechanisms (circannuality, photorefractorimes) can also drive seasonal changes in ARC Kiss 1 expression and reproduction (Milesi, Simonneaux, \& Klosen, 2017; Sáenz de Miera et al., 2014), thus indicating complex pathways in the long-term regulation of the Kp neuronal system.

\section{5 | CONCLUSION}

The discovery of the potent reproductive effect of Kp/Kiss $1 \mathrm{R}$ signaling in all mammalian species including humans has revolutionized the understanding of the neuroendocrine control of reproductive activity. Furthermore, Kp neurons are now considered as a hub where internal and external information are integrated to adjust reproductive activity. Thus, a number of factors known to alter reproduction, such as lactation, metabolic disease, stress, and aging, impact Kp synthesis and action. This review highlighted that daily and seasonal cues as well fine-tune Kp expression in order to adjust breeding activity to the best time of the day and the year. These findings may have direct application both in the clinic and for agronomy. Thus, circadian disruption has been reported to shift the LH surge timing and alter the ovarian cycle robustness, and it is possible that $\mathrm{Kp}$ administration, as already performed to treat some case of human infertility (Prague \& Dhillo, 2015 for review), may help women to recover regular reproductive cycles. In agronomy, the control of seasonal breeding is an important economic challenge, and current studies indicate that appropriate treatment with $\mathrm{Kp}$ agonists may help to manage livestock reproduction (Beltramo \& Decourt, 2018 for review).

\section{ACKNOWLEDGMENTS}

The author thanks all PhD students who contribute(d), by their dedicated work, to disclose how Kp and RFRP-3 neurons are pivotal to integrate environmental cues to adjust reproduction to daily and seasonal cycles: Florent Revel, Laura Ansel, Caroline Ancel, Cristina Saenz de Miera, Raja Talbi, David Chassard, Jo Henningsen, Sébastien Milesi, Thibault Bahougne, Fernando Cazarez Marquez, Hassan Ainani, Eleni Angelopoulou, and Clarisse Quignon. The author is also grateful to William J. Schwartz and Richard Piet for a critical reading of this manuscript.

\section{CONFLICT OF INTEREST}

Author has no conflict of interest.

\section{ORCID}

Valérie Simonneaux (iD) https://orcid. org/0000-0002-6004-7850

\section{REFERENCES}

Adachi, S., Yamada, S., Takatsu, Y., Matsui, H., Kinoshita, M., Takase, K., ... Maeda, K. (2007). Involvement of anteroventral periventricular metastin/kisspeptin neurons in estrogen positive feedback action on luteinizing hormone release in female rats. Journal of Reproduction and Development, 53, 367-378. https://doi. org/10.1262/jrd.18146

Ainani, H., Achaâban, M. R., Tibary, A., Pévet, P., Simonneaux, V., \& El Allali, K. (2018). Environmental and neuroendocrine control of breeding activity in the dromedary camel. Revue Marocaine des Sciences Agronomiques et Vétérinaires, 6(2), 143-157.

Ancel, C., Bentsen, A. H., Sébert, M.-E., Tena-Sempere, M., Mikkelsen, J. D., \& Simonneaux, V. (2012). Stimulatory effect of RFRP-3 on the gonadotrophic axis in the male Syrian hamster: The exception proves the rule. Endocrinology, 153, 1352-1363. https://doi. org/10.1210/en.2011-1622

Anderson, G. M., Hardy, S. L., Valent, M., Billings, H. J., Connors, J. M., \& Goodman, R. L. (2003). Evidence that thyroid hormones act in the ventromedial preoptic area and the premammillary region of the brain to allow the termination of the breeding season in the ewe. Endocrinology, 144, 2892-2901. https://doi.org/10.1210/ en.2003-0322

Ansel, L., Bentsen, A. H., Ancel, C., Bolborea, M., Klosen, P., Mikkelsen, J. D., \& Simonneaux, V. (2011). Peripheral kisspeptin reverses short photoperiod-induced gonadal regression in Syrian hamsters by promoting GNRH release. Reproduction, 142, 417425. https://doi.org/10.1530/REP-10-0313

Ansel, L., Bolborea, M., Bentsen, A. H., Klosen, P., Mikkelsen, J. D., \& Simonneaux, V. (2010). Differential regulation of kiss1 expression by melatonin and gonadal hormones in male and female Syrian hamsters. Journal of Biological Rhythms, 25, 81-91. https://doi. org/10.1177/0748730410361918

Barrell, G. K., Moenter, S. M., Caraty, A., \& Karsch, F. J. (1992). Seasonal changes of gonadotropin-releasing hormone secretion in the ewe. Biology of Reproduction, 46, 1130-1135. https://doi. org/10.1095/biolreprod46.6.1130

Barrell, G. K., Ridgway, M. J., Wellby, M., Pereira, A., Henry, B. A., \& Clarke, I. J. (2016). Expression of regulatory neuropeptides in the hypothalamus of red deer (Cervus elaphus) reveals anomalous relationships in the seasonal control of appetite and reproduction. General and Comparative Endocrinology, 229, 1-7. https://doi. org/10.1016/j.ygcen.2016.02.020

Barrett, P., Ebling, F. J. P., Schuhler, S., Wilson, D., Ross, A. W., Warner, A., ... Morgan, P. J. (2007). Hypothalamic thyroid hormone catabolism acts as a gatekeeper for the seasonal control of body weight and reproduction. Endocrinology, 148, 3608-3617. https://doi. org/10.1210/en.2007-0316

Bartness, T. J., Goldman, B. D., \& Bittman, E. L. (1991). SCN lesions block responses to systemic melatonin infusions in Siberian hamsters. American Journal of Physiology, 260, R102-R112.

Bartness, T. J., Powers, J. B., Hastings, M. H., Bittman, E. L., \& Goldman, B. D. (1993). The timed infusion paradigm for melatonin delivery: What has it taught us about the melatonin signal, its reception, and the photoperiodic control of seasonal responses? Journal of Pineal Research, 15, 161-190. https://doi.org/10.1111/j.1600079X.1993.tb00903.x

Bartzen-Sprauer, J., Klosen, P., Ciofi, P., Mikkelsen, J. D., \& Simonneaux, V. (2014). Photoperiodic co-regulation of kisseptin, neurokinin $\mathrm{B}$ and dynorphin in the hypothalamus of a seasonal 
rodent. Journal of Neuroendocrinology, 26, 510-520. https://doi. org/10.1111/jne.12171

Beltramo, M., Dardente, H., Cayla, X., \& Caraty, A. (2014). Cellular mechanisms and integrative timing of neuroendocrine control of GnRH secretion by kisspeptine. Molecular and Cellular Endocrinology, 382, 387-399. https://doi.org/10.1016/j. mce.2013.10.015

Beltramo, M., \& Decourt, C. (2018). Towards new strategies to manage livestock reproduction using kisspeptin analogs. Theriogenology, 112, 2-10. https://doi.org/10.1016/j.theriogenology.2017.08.026

Berson, D. M. (2002). Phototransduction by retinal ganglion cells that set the circadian clock. Science, 295, 1070-1073. https://doi. org/10.1126/science.1067262

Boufermes, R., Richard, N., Le Moguen, K., Amirat, Z., Khammar, F., \& Kottler, M. L. (2014). Seasonal expression of KiSS-1 and the pituitary gonadotropins LH $\beta$ and FSH $\beta$ in adult male Libyan jird (Meriones libycus). Animal Reproduction Science, 147, 56-63. https://doi.org/10.1016/j.anireprosci.2014.04.001

Brown-Grant, K., \& Raisman, G. (1977). Abnormalities in reproductive function associated with the destruction of the suprachiasmatic nuclei in female rats. Proceedings of the Royal Society of London. Series B, Biological Sciences, 198, 279-296. https://doi. org/10.1098/rspb.1977.0098

Cahill, D. J., Wardle, P. G., Harlow, C. R., \& Hull, M. G. (1998). Onset of the preovulatory luteinizing hormone surge: Diurnal timing and critical follicular prerequisites. Fertility and Sterility, 70, 56-59. https://doi.org/10.1016/S0015-0282(98)00113-7

Cai, W., Rambaud, J., Teboul, M., Masse, I., Benoit, G., Gustafsson, J.-A., ... Pongratz, I. (2008). Expression levels of estrogen receptor are modulated by components of the molecular clock. Molecular and Cellular Biology, 28, 784-793. https://doi.org/10.1128/ MCB.00233-07

Caraty, A., Franceschini, I., \& Hoffman, G. E. (2010). Kisspeptin and the preovulatory gonadotrophin-releasing hormone/luteinising hormone surge in the ewe: Basic aspects and potential applications in the control of ovulation. Journal of Neuroendocrinology, 22, $710-715$.

Caraty, A., Smith, J. T., Lomet, D., Ben Saïd, S., Morrissey, A., Cognie, J., ... Clarke, I. J. (2007). Kisspeptin synchronizes preovulatory surges in cyclical ewes and causes ovulation in seasonally acyclic ewes. Endocrinology, 148, 5258-5267. https://doi.org/10.1210/ en.2007-0554

Chalivoix, S., Bagnolini, A., Caraty, A., Cognié, J., Malpaux, B., \& Dufourny, L. (2010). Effects of photoperiod on kisspeptin neuronal populations of the ewe diencephalon in connection with reproductive function. Journal of Neuroendocrinology, 22, 110-118. https:// doi.org/10.1111/j.1365-2826.2009.01939.x

Chappell, P. E., White, R. S., \& Mellon, P. L. (2003). Circadian gene expression regulates pulsatile gonadotropin-releasing hormone (GnRH) secretory patterns in the hypothalamic GnRH-secreting GT1-7 cell line. Journal of Neuroscience, 23, 11202-11213. https:// doi.org/10.1523/JNEUROSCI.23-35-11202.2003

Chassard, D., Bur, I., Poirel, V.-J., Mendoza, J., \& Simonneaux, V. (2015). Evidence for a putative circadian kiss-clock in the hypothalamic AVPV in female mice. Endocrinology, 156, 2999-3011. https://doi.org/10.1210/en.2014-1769

Chen, H., Zhao, L., Kumazawa, M., Yamauchi, N., Shigeyoshi, Y., Hashimoto, S., \& Hattori, M. (2013). Downregulation of core clock gene Bmall attenuates expression of progesterone and prostaglandin biosynthesis-related genes in rat luteinizing granulosa cells. American Journal of Physiology-Cell Physiology, 304, C1131-C1140. https://doi.org/10.1152/ajpcell.00008.2013

Cheng, G., Coolen, L. M., Padmanabhan, V., Goodman, R. L., \& Lehman, M. N. (2010). The kisspeptin/neurokinin B/dynorphin (KNDy) cell population of the arcuate nucleus: Sex differences and effects of prenatal testosterone in sheep. Endocrinology, 151, 301311. https://doi.org/10.1210/en.2009-0541

Cheong, R. Y., Porteous, R., Chambon, P., Ábrahám, I., \& Herbison, A. E. (2014). Effects of neuron-specific estrogen receptor (ER) $\alpha$ and $\mathrm{ER} \beta$ deletion on the acute estrogen negative feedback mechanism in adult female mice. Endocrinology, 155, 1418-1427. https://doi. org/10.1210/en.2013-1943

Choe, H. K., Kim, H.-D., Park, S. H., Lee, H.-W., Park, J.-Y., Seong, J. Y., ... Kim, K. (2013). Synchronous activation of gonadotropinreleasing hormone gene transcription and secretion by pulsatile kisspeptin stimulation. Proceedings of the National Academy of Sciences of the United States of America, 110, 5677-5682. https:// doi.org/10.1073/pnas.1213594110

Christian, C. A., Mobley, J. L., \& Moenter, S. M. (2005). Diurnal and estradiol-dependent changes in gonadotropin-releasing hormone neuron firing activity. Proceedings of the National Academy of Sciences of the United States of America, 102, 15682-15687. https:// doi.org/10.1073/pnas.0504270102

Christian, C. A., \& Moenter, S. M. (2008). Vasoactive intestinal polypeptide can excite gonadotropin-releasing hormone neurons in a manner dependent on estradiol and gated by time of day. Endocrinology, 149, 3130-3136. https://doi.org/10.1210/en.2007-1098

Christian, C. A., \& Moenter, S. M. (2010). The neurobiology of preovulatory and estradiol-induced gonadotropin-releasing hormone surges. Endocrine Reviews, 31, 544-577. https://doi.org/10.1210/ er.2009-0023

Chu, A., Zhu, L., Blum, I. D., Mai, O., Leliavski, A., Fahrenkrug, J., ... Storch, K.-F. (2013). Global but not gonadotrope-specific disruption of Bmall abolishes the luteinizing hormone surge without affecting ovulation. Endocrinology, 154, 2924-2935. https://doi.org/10.1210/ en.2013-1080

Ciechanowska, M., Łapot, M., Paruszewska, E., Radawiec, W., \& Przekop, F. (2017). The influence of dopaminergic system inhibition on biosynthesis of gonadotrophin-releasing hormone $(\mathrm{GnRH})$ and GnRH receptor in anoestrous sheep; hierarchical role of kisspeptin and RFamide-related peptide-3 (RFRP-3). Reproduction, Fertility, and Development, 30(4), 672-680.

Clarke, I. J., Sari, I. P., Qi, Y., Smith, J. T., Parkington, H. C., Ubuka, T., ... Bentley, G. E. (2008). Potent action of RFamide-related peptide-3 on pituitary gonadotropes indicative of a hypophysiotropic role in the negative regulation of gonadotropin secretion. Endocrinology, 149, 5811-5821. https://doi.org/10.1210/en.2008-0575

Clarkson, J., d'Anglemont de Tassigny, X., Moreno, A. S., Colledge, W. H., \& Herbison, A. E. (2008). Kisspeptin-GPR54 signaling is essential for preovulatory gonadotropin-releasing hormone neuron activation and the luteinizing hormone surge. Journal of Neuroscience, 28, 8691-8697. https://doi.org/10.1523/ JNEUROSCI.1775-08.2008

Clarkson, J., Han, S. Y., Piet, R., McLennan, T., Kane, G. M., Ng, J., ... Herbison, A. E. (2017). Definition of the hypothalamic GnRH pulse generator in mice. Proceedings of the National Academy of Sciences of the United States of America, 114, E10216-E10223. https://doi. org/10.1073/pnas.1713897114 
Clarkson, J., \& Herbison, A. E. (2006). Postnatal development of kisspeptin neurons in mouse hypothalamus; sexual dimorphism and projections to gonadotropin-releasing hormone neurons. Endocrinology, 147, 5817-5825. https://doi.org/10.1210/en.2006-0787

Cravo, R. M., Margatho, L. O., Osborne-Lawrence, S., Donato, J., Atkin, S., Bookout, A. L., ... Elias, C. F. (2011). Characterization of Kiss1 neurons using transgenic mouse models. Neuroscience, 173, 37-56. https://doi.org/10.1016/j.neuroscience.2010.11.022

Dardente, H. (2012). Melatonin-dependent timing of seasonal reproduction by the pars tuberalis: Pivotal roles for long daylengths and thyroid hormones: Melatonin-dependent timing of seasonal reproduction by the pars tuberalis. Journal of Neuroendocrinology, 24, 249-266. https://doi.org/10.1111/j.1365-2826.2011.02250.x

Dardente, H., Hazlerigg, D. G., \& Ebling, F. J. P. (2014). Thyroid hormone and seasonal rhythmicity. Frontiers in Endocrinology, 5(19), 1-11.

Dardente, H., Wyse, C. A., Birnie, M. J., Dupré, S. M., Loudon, A. S. I., Lincoln, G. A., \& Hazlerigg, D. G. (2010). A molecular switch for photoperiod responsiveness in mammals. Current Biology, 20, 2193-2198. https://doi.org/10.1016/j.cub.2010.10.048

Decourt, C., Anger, K., Robert, V., Lomet, D., Bartzen-Sprauer, J., Caraty, A., ... Beltramo, M. (2016). No evidence that RFamide-related peptide 3 directly modulates LH secretion in the ewe. Endocrinology, 157, 1566-1575. https://doi.org/10.1210/en.2015-1854

de Oliveira, A. C., Andreotti, S., Sertie, R. A. L., Campana, A. B., de Proença, A. R. G., Vasconcelos, R. P., ... Lima, F. B. (2018). Combined treatment with melatonin and insulin improves glycemic control, white adipose tissue metabolism and reproductive axis of diabetic male rats. Life Sciences, 199, 158-166. https://doi. org/10.1016/j.lfs.2018.02.040

de Roux, N., Genin, E., Carel, J.-C., Matsuda, F., Chaussain, J.-L., \& Milgrom, E. (2003). Hypogonadotropic hypogonadism due to loss of function of the KiSS1-derived peptide receptor GPR54. Proceedings of the National Academy of Sciences of the United States of America, 100, 10972-10976. https://doi.org/10.1073/ pnas. 1834399100

Dhillo, W. S., Chaudhri, O. B., Patterson, M., Thompson, E. L., Murphy, K. G., Badman, M. K., ... Bloom, S. R. (2005). Kisspeptin-54 stimulates the hypothalamic-pituitary gonadal axis in human males. Journal of Clinical Endocrinology and Metabolism, 90, 6609-6615. https://doi.org/10.1210/jc.2005-1468

Dhillo, W. S., Chaudhri, O. B., Thompson, E. L., Murphy, K. G., Patterson, M., Ramachandran, R., ... Bloom, S. R. (2007). Kisspeptin-54 stimulates gonadotropin release most potently during the preovulatory phase of the menstrual cycle in women. Journal of Clinical Endocrinology and Metabolism, 92, 3958-3966. https:// doi.org/10.1210/jc.2007-1116

Dolatshad, H., Campbell, E. A., O'Hara, L., Maywood, E. S., Hastings, M. H., \& Johnson, M. H. (2006). Developmental and reproductive performance in circadian mutant mice. Human Reproduction, 21, 68-79. https://doi.org/10.1093/humrep/dei313

Dufourny, L., Gennetay, D., Martinet, S., Lomet, D., \& Caraty, A. (2016). The content of thyroid hormone receptor $\alpha$ in ewe kisspeptin neurones is not season-dependent. Journal of Neuroendocrinology, $28,12344$.

Estrada, K. M., Clay, C. M., Pompolo, S., Smith, J. T., \& Clarke, I. J. (2006). Elevated KiSS-1 expression in the arcuate nucleus prior to the cyclic preovulatory gonadotrophin-releasing hormone/lutenising hormone surge in the ewe suggests a stimulatory role for kisspeptin in oestrogen-positive feedback. Journal of Neuroendocrinology, 18, 806-809. https://doi.org/10.1111/j.1365-2826.2006.01485.x

Franceschini, I., Lomet, D., Cateau, M., Delsol, G., Tillet, Y., \& Caraty, A. (2006). Kisspeptin immunoreactive cells of the ovine preoptic area and arcuate nucleus co-express estrogen receptor alpha. Neuroscience Letters, 401, 225-230. https://doi.org/10.1016/j. neulet.2006.03.039

Francl, J. M., Kaur, G., \& Glass, J. D. (2010). Regulation of vasoactive intestinal polypeptide release in the suprachiasmatic nucleus circadian clock. NeuroReport, 21, 1055-1059. https://doi.org/10.1097/ WNR.0b013e32833fcba4

Funabashi, T., Aiba, S., Sano, A., Shinohara, K., \& Kimura, F. (1999). Intracerebroventricular injection of arginine-vasopressin V1 receptor antagonist attenuates the surge of luteinizing hormone and prolactin secretion in proestrous rats. Neuroscience Letters, 260, 37-40. https://doi.org/10.1016/S0304-3940(98)00940-9

Funabashi, T., Shinohara, K., Mitsushima, D., \& Kimura, F. (2000). Gonadotropin-releasing hormone exhibits circadian rhythm in phase with arginine-vasopressin in co-cultures of the female rat preoptic area and suprachiasmatic nucleus. Journal of Neuroendocrinology, $12,521-528$.

Gibson, E. M., Humber, S. A., Jain, S., Williams, W. P., Zhao, S., Bentley, G. E., ... Kriegsfeld, L. J. (2008). Alterations in RFamiderelated peptide expression are coordinated with the preovulatory luteinizing hormone surge. Endocrinology, 149, 4958-4969. https:// doi.org/10.1210/en.2008-0316

Gillespie, J. M. A., Chan, B. P. K., Roy, D., Cai, F., \& Belsham, D. D. (2003). Expression of circadian rhythm genes in gonadotropinreleasing hormone-secreting GT1-7 neurons. Endocrinology, 144, 5285-5292. https://doi.org/10.1210/en.2003-0802

Gingerich, S., Wang, X., Lee, P. K. P., Dhillon, S. S., Chalmers, J. A., Koletar, M. M., \& Belsham, D. D. (2009). The generation of an array of clonal, immortalized cell models from the rat hypothalamus: Analysis of melatonin effects on kisspeptin and gonadotropin-inhibitory hormone neurons. Neuroscience, 162, 1134-1140. https://doi.org/10.1016/j.neuroscience.2009.05.026

Goodman, R. L., \& Inskeep, E. K. (2014). Control of the ovarian cycle of the sheep. In T. M. Plant \& A. J. Zeleznic (Eds.), Knobil and Neill's physiology of reprodution (4th ed., Chp. 27, pp. 1259-1305). Amsterdam, the Netherlands: Academic Press.

Goodman, R. L., \& Lehman, M. N. (2012). Kisspeptin neurons from mice to men: Similarities and differences. Endocrinology, 153, 5105-5118. https://doi.org/10.1210/en.2012-1550

Goodman, R. L., Maltby, M. J., Millar, R. P., Hileman, S. M., Nestor, C. C., Whited, B., ... Lehman, M. N. (2012). Evidence that dopamine acts via kisspeptin to hold GnRH pulse frequency in check in anestrous ewes. Endocrinology, 153, 5918-5927. https://doi. org/10.1210/en.2012-1611

Gottsch, M. L., Cunningham, M. J., Smith, J. T., Popa, S. M., Acohido, B. V., Crowley, W. F., ... Steiner, R. A. (2004). A role for kisspeptins in the regulation of gonadotropin secretion in the mouse. Endocrinology, 145, 4073-4077. https://doi.org/10.1210/ en.2004-0431

Gottsch, M. L., Navarro, V. M., Zhao, Z., Glidewell-Kenney, C., Weiss, J., Jameson, J. L., ... Steiner, R. A. (2009). Regulation of Kiss 1 and dynorphin gene expression in the murine brain by classical and nonclassical estrogen receptor pathways. Journal of Neuroscience, 29, 9390-9395. https://doi.org/10.1523/ JNEUROSCI.0763-09.2009 
Greenwald-Yarnell, M. L., Marsh, C., Allison, M. B., Patterson, C. M., Kasper, C., MacKenzie, A., ... Myers, M. G. (2016). ER $\alpha$ in Tac2 neurons regulates puberty onset in female mice. Endocrinology, 157, 1555-1565. https://doi.org/10.1210/en.2015-1928

Greives, T. J., Humber, S. A., Goldstein, A. N., Scotti, M.-A. L., Demas, G. E., \& Kriegsfeld, L. J. (2008). Photoperiod and testosterone interact to drive seasonal changes in kisspeptin expression in siberian hamsters (Phodopus sungorus). Journal of Neuroendocrinology, 20, 1339-1347. https://doi.org/10.1111/j.1365-2826.2008.01790.x

Greives, T. J., Mason, A. O., Scotti, M.-A. L., Levine, J., Ketterson, E. D., Kriegsfeld, L. J., \& Demas, G. E. (2007). Environmental control of kisspeptin: Implications for seasonal reproduction. Endocrinology, 148, 1158-1166. https://doi.org/10.1210/en.2006-1249

Guillemin, R. (1977). Purification, isolation, and primary structure of the hypothalamic luteinizing hormone-releasing factor of ovine origin. American Journal of Obstetrics and Gynecology, 129, 214-218. https://doi.org/10.1016/0002-9378(77)90749-9

Han, S.-K., Gottsch, M. L., Lee, K. J., Popa, S. M., Smith, J. T., Jakawich, S. K., ... Herbison, A. E. (2005). Activation of gonadotropin-releasing hormone neurons by kisspeptin as a neuroendocrine switch for the onset of puberty. Journal of Neuroscience, 25, 11349-11356. https://doi.org/10.1523/JNEUROSCI.3328-05.2005

Han, S. Y., McLennan, T., Czieselsky, K., \& Herbison, A. E. (2015). Selective optogenetic activation of arcuate kisspeptin neurons generates pulsatile luteinizing hormone secretion. Proceedings of the National Academy of Sciences of the United States of America, 112, 13109-13114. https://doi.org/10.1073/pnas.1512243112

Hanon, E. A., Lincoln, G. A., Fustin, J.-M., Dardente, H., MassonPévet, M., Morgan, P. J., \& Hazlerigg, D. G. (2008). Ancestral TSH mechanism signals summer in a photoperiodic mammal. Current Biology, 18, 1147-1152. https://doi.org/10.1016/j.cub.2008.06.076

Hanon, E. A., Routledge, K., Dardente, H., Masson-Pévet, M., Morgan, P. J., \& Hazlerigg, D. G. (2010). Effect of photoperiod on the thyroid-stimulating hormone neuroendocrine system in the European Hamster (Cricetus cricetus). Journal of Neuroendocrinology, 22, 51-55. https://doi.org/10.1111/j.1365-2826.2009.01937.x

Harney, J. P., Scarbrough, K., Rosewell, K. L., \& Wise, P. M. (1996). In vivo antisense antagonism of vasoactive intestinal peptide in the suprachiasmatic nuclei causes aging-like changes in the estradiolinduced luteinizing hormone and prolactin surges. Endocrinology, 137, 3696-3701. https://doi.org/10.1210/endo.137.9.8756535

Hattar, S., Liao, H. W., Takao, M., Berson, D. M., \& Yau, K. W. (2002). Melanopsin-containing retinal ganglion cells: Architecture, projections, and intrinsic photosensitivity. Science, 295, 1065-1070. https://doi.org/10.1126/science.1069609

Hazlerigg, D., \& Simonneaux, V. (2015). Seasonal reproduction in mammals. In T. M. Plant \& A. J. Zeleznic (Eds)., Knobil and Neill's physiology of reprodution (4th ed., Chp. 34, pp. 1575-1660). Amsterdam, the Netherlands: Academic Press.

Henningsen, J. B., Ancel, C., Mikkelsen, J. D., Gauer, F., \& Simonneaux, V. (2017). Roles of RFRP-3 in the daily and seasonal regulation of reproductive activity in female Syrian hamsters. Endocrinology, $158,652-663$.

Henningsen, J. B., Gauer, F., \& Simonneaux, V. (2016). RFRP neurons-The doorway to understanding seasonal reproduction in mammals. Frontiers in Endocrinology, 7, 36.

Henson, J. R., Carter, S. N., \& Freeman, D. A. (2013). Exogenous T 3 elicits long day-like alterations in testis size and the RFamides kisspeptin and gonadotropin-inhibitory hormone in short-day Siberian hamsters. Journal of Biological Rhythms, 28, 193-200. https://doi. org/10.1177/0748730413487974

Herbison, A. (2015). Physiology of the adult gonadotropin-releasing hormone neuronal network. In T. M. Plant \& A. J. Zeleznic (Eds.), Knobil and Neill's physiology of reproduction (4th ed., Chp. 11, pp. 339-468). Amsterdam, the Netherlands: Academic Press.

Herbison, A. E., d'Anglemont de Tassigny, X., Doran, J., \& Colledge, W. H. (2010). Distribution and postnatal development of Gpr54 gene expression in mouse brain and gonadotropin-releasing hormone neurons. Endocrinology, 151, 312-321. https://doi.org/10.1210/ en.2009-0552

Herbison, A. E., \& Theodosis, D. T. (1992). Localization of oestrogen receptors in preoptic neurons containing neurotensin but not tyrosine hydroxylase, cholecystokinin or luteinizing hormone-releasing hormone in the male and female rat. Neuroscience, 50, 283-298. https://doi.org/10.1016/0306-4522(92)90423-Y

Hickok, J. R., \& Tischkau, S. A. (2010). In vivo circadian rhythms in gonadotropin-releasing hormone neurons. Neuroendocrinology, 91, 110-120. https://doi.org/10.1159/000243163

Hillier, S. G. (1994). Current concepts of the roles of follicle stimulating hormone and luteinizing hormone in folliculogenesis. Human Reproduction, 9, 188-191. https://doi.org/10.1093/oxfordjournals. humrep.a138480

Hoffman, G. E., Le, W. W., Franceschini, I., Caraty, A., \& Advis, J. P. (2011). Expression of Fos and in vivo median eminence release of LHRH identifies an active role for preoptic area kisspeptin neurons in synchronized surges of LH and LHRH in the ewe. Endocrinology, 152, 214-222. https://doi.org/10.1210/en.2010-0066

Honma, S. (2018). The mammalian circadian system: A hierarchical multi-oscillator structure for generating circadian rhythm. The Journal of Physiological Sciences, 68, 207-219. https://doi. org/10.1007/s12576-018-0597-5

Horvath, T. L., Cela, V., \& van der Beek, E. M. (1998). Gender-specific apposition between vasoactive intestinal peptide-containing axons and gonadotrophin-releasing hormone-producing neurons in the rat. Brain Research, 795, 277-281. https://doi.org/10.1016/ S0006-8993(98)00208-X

Hrabovszky, E., Ciofi, P., Vida, B., Horvath, M. C., Keller, E., Caraty, A., ... Kallo, I. (2010). The kisspeptin system of the human hypothalamus: Sexual dimorphism and relationship with gonadotropinreleasing hormone and neurokinin B neurons: Kisspeptin neurons in the human. European Journal of Neuroscience, 31, 1984-1998. https://doi.org/10.1111/j.1460-9568.2010.07239.x

Hrabovszky, E., Shughrue, P. J., Merchenthaler, I., Hajszán, T., Carpenter, C. D., Liposits, Z., \& Petersen, S. L. (2000). Detection of estrogen receptor- $\beta$ messenger ribonucleic acid and ${ }^{125}$ I-estrogen binding sites in luteinizing hormone-releasing hormone neurons of the rat brain. Endocrinology, 141, 3506-3509. https://doi. org/10.1210/endo.141.9.7788

Huijbregts, L., \& de Roux, N. (2010). KISS1 is down-regulated by 17ßestradiol in MDA-MB-231 cells through a nonclassical mechanism and loss of ribonucleic acid polymerase II binding at the proximal promoter. Endocrinology, 151, 3764-3772. https://doi.org/10.1210/ en.2010-0260

Irwig, M. S., Fraley, G. S., Smith, J. T., Acohido, B. V., Popa, S. M., Cunningham, M. J., ... Steiner, R. A. (2004). Kisspeptin activation of gonadotropin releasing hormone neurons and regulation of KiSS-1 mRNA in the male rat. Neuroendocrinology, 80, 264-272. https://doi.org/10.1159/000083140 
Jacobs, D. C., Veitch, R. E., \& Chappell, P. E. (2016). Evaluation of immortalized AVPV- and arcuate-specific neuronal kisspeptin cell lines to elucidate potential mechanisms of estrogen responsiveness and temporal gene expression in females. Endocrinology, 157, 3410-3419. https://doi.org/10.1210/en.2016-1294

Jin, X., Shearman, L. P., Weaver, D. R., Zylka, M. J., de Vries, G. J., \& Reppert, S. M. (1999). A molecular mechanism regulating rhythmic output from the suprachiasmatic circadian clock. Cell, 96, 57-68. https://doi.org/10.1016/S0092-8674(00)80959-9

Kalsbeek, A., Buijs, R. M., Engelmann, M., Wotjak, C. T., \& Landgraf, R. (1995). In vivo measurement of a diurnal variation in vasopressin release in the rat suprachiasmatic nucleus. Brain Research, 682, 75-82. https://doi. org/10.1016/0006-8993(95)00324-J

Kanasaki, H., Tselmeg, M., Oride, A., Sukhbaatar, U., Hara, T., \& Kyo, S. (2017). Pulsatile kisspeptin effectively stimulates gonadotropin-releasing hormone (GnRH)-producing neurons. Gynecological Endocrinology, 33, 721-727. https://doi.org/10.1080/09513590.20 17.1318277

Karsch, F. J., Bittman, E. L., Foster, D. L., Goodman, R. L., Legan, S. J., \& Robinson, J. E. (1984). Neuroendocrine basis of seasonal reproduction. Recent Progress in Hormone Research, 40, 185-232.

Kauffman, A. S., Gottsch, M. L., Roa, J., Byquist, A. C., Crown, A., Clifton, D. K., ... Tena-Sempere, M. (2007). Sexual differentiation of Kiss1 gene expression in the brain of the rat. Endocrinology, 148, 1774-1783. https://doi.org/10.1210/en.2006-1540

Kerdelhué, B. D., Brown, S., Lenoir, V., Queenan Jr., J. T., Jones, G. S., Scholler, R., \& Jones Jr., H. W. (2002). Timing of initiation of the preovulatory luteinizing hormone surge and its relationship with the circadian cortisol rhythm in the human. Neuroendocrinology, 75, 158-163. https://doi.org/10.1159/000048233

Kinoshita, M., Tsukamura, H., Adachi, S., Matsui, H., Uenoyama, Y., Iwata, K., ... Maeda, K. (2005). Involvement of central metastin in the regulation of preovulatory luteinizing hormone surge and estrous cyclicity in female rats. Endocrinology, 146, 4431-4436. https://doi. org/10.1210/en.2005-0195

Kirilov, M., Clarkson, J., Liu, X., Roa, J., Campos, P., Porteous, R., ... Herbison, A. E. (2013). Dependence of fertility on kisspeptinGpr54 signaling at the GnRH neuron. Nature Communications, 4, 2492-2503. https://doi.org/10.1038/ncomms3492

Klingman, K. M., Marsh, E. E., Klerman, E. B., Anderson, E. J., \& Hall, J. E. (2011). Absence of circadian rhythms of gonadotropin secretion in women. Journal of Clinical Endocrinology and Metabolism, 96, 1456-1461. https://doi.org/10.1210/jc.2010-2739

Klosen, P., Bienvenu, C., Demarteau, O., Dardente, H., Guerrero, H., Pévet, P., \& Masson-Pévet, M. (2002). The mt1 melatonin receptor and RORbeta receptor are co-localized in specific TSH-immunoreactive cells in the pars tuberalis of the rat pituitary. Journal of Histochemistry and Cytochemistry, 50, 1647-1657. https://doi. org/10.1177/002215540205001209

Klosen, P., Sebert, M.-E., Rasri, K., Laran-Chich, M.-P., \& Simonneaux, V. (2013). TSH restores a summer phenotype in photoinhibited mammals via the RF-amides RFRP3 and kisspeptin. The FASEB Journal, 27, 2677-2686. https://doi.org/10.1096/ fj.13-229559

Kovanen, L., Saarikoski, S. T., Aromaa, A., Lönnqvist, J., \& Partonen, T. (2010). ARNTL (BMAL1) and NPAS2 gene variants contribute to fertility and seasonality. PLoS One, 5, e10007.
Kriegsfeld, L. J. (2013). Circadian regulation of kisspeptin in female reproductive functioning. Advances in Experimental Medicine and Biology, 784, 385-410. https://doi.org/10.1007/978-1-4614-6199-9

Kriegsfeld, L. J., Jennings, K. J., Bentley, G. E., \& Tsutsui, K. (2018). Gonadotropin-inhibitory hormone $(\mathrm{GnIH})$ and its mammalian ortholog RFamide-related peptide-3 (RFRP-3): Discovery and functional implications for reproduction and stress. Journal of Neuroendocrinology, 30(7), e12597. https://doi.org/10.1111/ jne. 12597

Kriegsfeld, L. J., Mei, D. F., Bentley, G. E., Ubuka, T., Mason, A. O., Inoue, K., ... Silver, R. (2006). Identification and characterization of a gonadotropin-inhibitory system in the brains of mammals. Proceedings of the National Academy of Sciences of the United States of America, 103, 2410-2415. https://doi.org/10.1073/ pnas.0511003103

Król, E., Douglas, A., Dardente, H., Birnie, M. J., Vinne, V., Eijer, W. G., ... Hut, R. A. (2012). Strong pituitary and hypothalamic responses to photoperiod but not to 6-methoxy-2-benzoxazolinone in female common voles (Microtus arvalis). General and Comparative Endocrinology, 179, 289-295. https://doi.org/10.1016/j. ygcen.2012.09.004

Lee, J. H., Miele, M. E., Hicks, D. J., Phillips, K. K., Trent, J. M., Weissman, B. E., \& Welch, D. R. (1996). KiSS-1, a novel human malignant melanoma metastasis-suppressor gene. Journal of the National Cancer Institute, 88, 1731-1737. https://doi.org/10.1093/ jnci/88.23.1731

Legan, S. J., \& Karsch, F. J. (1975). A daily signal for the LH surge in the rat. Endocrinology, 96, 57-62. https://doi.org/10.1210/ endo-96-1-57

León, S., Barroso, A., Vázquez, M. J., García-Galiano, D., ManfrediLozano, M., Ruiz-Pino, F., ... Tena-Sempere, M. (2016). Direct actions of kisspeptins on GnRH neurons permit attainment of fertility but are insufficient to fully preserve gonadotropic axis activity. Scientific Reports, 6, 19206. https://doi.org/10.1038/srep19206

León, S., García-Galiano, D., Ruiz-Pino, F., Barroso, A., ManfrediLozano, M., Romero-Ruiz, A., ... Tena-Sempere, M. (2014). Physiological roles of gonadotropin-inhibitory hormone signaling in the control of mammalian reproductive axis: Studies in the NPFF1 receptor null mouse. Endocrinology, 155, 2953-2965. https://doi. org/10.1210/en.2014-1030

León, S., \& Tena-Sempere, M. (2015). Dissecting the roles of gonadotropin-inhibitory hormone in mammals: Studies using pharmacological tools and genetically modified mouse models. Frontiers in Endocrinology, 6, 189.

Levine, J. (2015). Neuroendocrine control of the ovarian cycle of the rat. In T. M. Plant \& A. J. Zeleznic (Eds.), Knobil and Neill's physiology of reprodution (4th ed., Chp. 26, pp. 1199-1258). Amsterdam, the Netherlands: Academic Press.

Li, Q., Rao, A., Pereira, A., Clarke, I. J., \& Smith, J. T. (2011). Kisspeptin cells in the ovine arcuate nucleus express prolactin receptor but not melatonin receptor. Journal of Neuroendocrinology, 23, 871-882. https://doi.org/10.1111/j.1365-2826.2011.02195.x

Li, S. N., Xue, H. L., Zhang, Q., Xu, J. H., Wang, S., Chen, L., \& Xu, L. X. (2015). Photoperiod regulates the differential expression of KiSS-1 and GPR54 in various tissues and sexes of striped hamster. Genetics and Molecular Research, 14, 13894-13905. https://doi. org/10.4238/2015.October.29.10

Lincoln, G. A., \& Short, R. V. (1980). Seasonal breeding: Nature's contraceptive. Recent Progress in Hormone Research, 36, 1-52. 
Lomet, D., Cognié, J., Chesneau, D., Dubois, E., Hazlerigg, D., \& Dardente, H. (2018). The impact of thyroid hormone in seasonal breeding has a restricted transcriptional signature. Cellular and Molecular Life Sciences, 75, 905-919. https://doi.org/10.1007/ s00018-017-2667-x

Malpaux, B., Daveau, A., Maurice-Mandon, F., Duarte, G., \& Chemineau, P. (1998). Evidence that melatonin acts in the premammillary hypothalamic area to control reproduction in the ewe: Presence of binding sites and stimulation of luteinizing hormone secretion by in situ microimplant delivery. Endocrinology, 139, 1508-1516. https://doi.org/10.1210/endo.139.4.5879

Mansuy, V., Risold, P.-Y., Glauser, M., Fraichard, A., \& Pralong, F. P. (2009). Expression of the GABAA receptor associated protein Gec1 is circadian and dependent upon the cellular clock machinery in $\mathrm{GnRH}$ secreting GnV-3 cells. Molecular and Cellular Endocrinology, 307, 68-76. https://doi.org/10.1016/j.mce.2009.02.029

Matheson, A., O'Brien, L., \& Reid, J.-A. (2014). The impact of shiftwork on health: A literature review. Journal of Clinical Nursing, 23, 3309-3320. https://doi.org/10.1111/jocn.12524

Mayer, C., Acosta-Martinez, M., Dubois, S. L., Wolfe, A., Radovick, S., Boehm, U., \& Levine, J. E. (2010). Timing and completion of puberty in female mice depend on estrogen receptor alpha-signaling in kisspeptin neurons. Proceedings of the National Academy of Sciences of the United States of America, 107, 22693-22698. https:// doi.org/10.1073/pnas.1012406108

Maywood, E. S., Bittman, E. L., \& Hastings, M. H. (1996). Lesions of the melatonin- and androgen-responsive tissue of the dorsomedial nucleus of the hypothalamus block the gonadal response of male Syrian hamsters to programmed infusions of melatonin. Biology of Reproduction, 54, 470-477. https://doi.org/10.1095/ biolreprod54.2.470

McElhinny, T. L., Sisk, C. L., Holekamp, K. E., \& Smale, L. (1999). A morning surge in plasma luteinizing hormone coincides with elevated Fos expression in gonadotropin-releasing hormone-immunoreactive neurons in the diurnal rodent, Arvicanthis niloticus. Biology of Reproduction, 61, 1115-1122. https://doi.org/10.1095/ biolreprod61.4.1115

Menaker, M., Murphy, Z. C., \& Sellix, M. T. (2013). Central control of peripheral circadian oscillators. Current Opinion in Neurobiology, 23, 741-746. https://doi.org/10.1016/j.conb.2013.03.003

Merkley, C. M., Porter, K. L., Coolen, L. M., Hileman, S. M., Billings, H. J., Drews, S., ... Lehman, M. N. (2012). KNDy (kisspeptin/neurokinin $\mathrm{B} /$ dynorphin) neurons are activated during both pulsatile and surge secretion of LH in the ewe. Endocrinology, 153, 54065414. https://doi.org/10.1210/en.2012-1357

Messager, S., Chatzidaki, E. E., Ma, D., Hendrick, A. G., Zahn, D., Dixon, J., ... Aparicio, S. A. (2005). Kisspeptin directly stimulates gonadotropin-releasing hormone release via G protein-coupled receptor 54. Proceedings of the National Academy of Sciences of the United States of America, 102, 1761-1766. https://doi.org/10.1073/ pnas.0409330102

Milesi, S., Simonneaux, V., \& Klosen, P. (2017). Downregulation of deiodinase 3 is the earliest event in photoperiodic and photorefractory activation of the gonadotropic axis in seasonal hamsters. Scientific Reports, 7, 17739. https://doi.org/10.1038/ s41598-017-17920-y

Miller, B. H., Olson, S. L., Levine, J. E., Turek, F. W., Horton, T. H., \& Takahashi, J. S. (2006). Vasopressin regulation of the proestrous luteinizing hormone surge in wild-type and Clock mutant mice.
Biology of Reproduction, 75, 778-784. https://doi.org/10.1095/ biolreprod.106.052845

Miller, B. H., Olson, S. L., Turek, F. W., Levine, J. E., Horton, T. H., \& Takahashi, J. S. (2004). Circadian clock mutation disrupts estrous cyclicity and maintenance of pregnancy. Current Biology, 14, 13671373. https://doi.org/10.1016/j.cub.2004.07.055

Mohawk, J. A., Green, C. B., \& Takahashi, J. S. (2012). Central and peripheral circadian clocks in mammals. Annual Review of Neuroscience, 35, 445-462. https://doi.org/10.1146/ annurev-neuro-060909-153128

Moline, M. L., Albers, H. E., Todd, R. B., \& Moore-Ede, M. C. (1981). Light-dark entrainment of proestrous LH surges and circadian locomotor activity in female hamsters. Hormones and Behavior, 15, 451-458. https://doi.org/10.1016/0018-506X(81)90009-X

Murphy, M., Jethwa, P. H., Warner, A., Barrett, P., Nilaweera, K. N., Brameld, J. M., \& Ebling, F. J. P. (2012). Effects of manipulating hypothalamic triiodothyronine concentrations on seasonal body weight and torpor cycles in Siberian hamsters. Endocrinology, 153, 101-112. https://doi.org/10.1210/en.2011-1249

Nakane, Y., \& Yoshimura, T. (2014). Universality and diversity in the signal transduction pathway that regulates seasonal reproduction in vertebrates. Frontiers in Neuroscience, 8, 115.

Nakao, N., Ono, H., Yamamura, T., Anraku, T., Takagi, T., Higashi, K., ... Yoshimura, T. (2008). Thyrotrophin in the pars tuberalis triggers photoperiodic response. Nature, 452, 317-322. https://doi. org/10.1038/nature06738

Navarro, V. M., Castellano, J. M., Fernández-Fernández, R., Barreiro, M. L., Roa, J., Sanchez-Criado, J. E., ... Tena-Sempere, M. (2004). Developmental and hormonally regulated messenger ribonucleic acid expression of KiSS-1 and its putative receptor, GPR54, in rat hypothalamus and potent luteinizing hormone-releasing activity of KiSS-1 peptide. Endocrinology, 145, 4565-4574. https://doi. org/10.1210/en.2004-0413

Navarro, V. M., Castellano, J. M., McConkey, S. M., Pineda, R., RuizPino, F., Pinilla, L., ... Steiner, R. A. (2011). Interactions between kisspeptin and neurokinin B in the control of GnRH secretion in the female rat. American Journal of Physiology-Endocrinology and Metabolism, 300, E202-E210. https://doi.org/10.1152/ ajpendo.00517.2010

Navarro, V. M., Gottsch, M. L., Chavkin, C., Okamura, H., Clifton, D. K., \& Steiner, R. A. (2009). Regulation of gonadotropin-releasing hormone secretion by kisspeptin/dynorphin/neuroki$\operatorname{nin} \mathrm{B}$ neurons in the arcuate nucleus of the mouse. Journal of Neuroscience, 29, 11859-11866. https://doi.org/10.1523/ JNEUROSCI.1569-09.2009

Nicholls, T. J., Follett, B. K., Goldsmith, A. R., \& Pearson, H. (1988). Possible homologies between photorefractoriness in sheep and birds: The effect of thyroidectomy on the length of the ewe's breeding season. Reproduction, Nutrition, Development, 28, 375-385. https://doi.org/10.1051/rnd:19880304

Norman, R. L., Blake, C. A., \& Sawyer, C. H. (1973). Estrogen-dependent 24-hour periodicity in pituitary LH release in the female hamster. Endocrinology, 93, 965-970. https://doi.org/10.1210/ endo-93-4-965

Ono, H., Hoshino, Y., Yasuo, S., Watanabe, M., Nakane, Y., Murai, A., ... Yoshimura, T. (2008). Involvement of thyrotropin in photoperiodic signal transduction in mice. Proceedings of the National Academy of Sciences of the United States of America, 105, 1823818242. https://doi.org/10.1073/pnas.0808952105 
Palm, I. F., van Der Beek, E. M., Wiegant, V. M., Buijs, R. M., \& Kalsbeek, A. (1999). Vasopressin induces a luteinizing hormone surge in ovariectomized, estradiol-treated rats with lesions of the suprachiasmatic nucleus. Neuroscience, 93, 659-666. https://doi. org/10.1016/S0306-4522(99)00106-2

Piekarski, D. J., Jarjisian, S. G., Perez, L., Ahmad, H., Dhawan, N., Zucker, I., \& Kriegsfeld, L. J. (2014). Effects of pinealectomy and short day lengths on reproduction and neuronal RFRP-3, kisspeptin, and GnRH in female Turkish hamsters. Journal of Biological Rhythms, 29, 181-191. https://doi.org/10.1177/0748730414532423

Piet, R., Dunckley, H., Lee, K., \& Herbison, A. E. (2016). Vasoactive intestinal peptide excites GnRH neurons in male and female mice. Endocrinology, 157, 3621-3630. https://doi.org/10.1210/ en.2016-1399

Piet, R., Fraissenon, A., Boehm, U., \& Herbison, A. E. (2015). Estrogen permits vasopressin signaling in preoptic kisspeptin neurons in the female mouse. Journal of Neuroscience, 35, 6881-6892. https://doi. org/10.1523/JNEUROSCI.4587-14.2015

Piet, R., Kalil, B., McLennan, T., Porteous, R., Czieselsky, K., \& Herbison, A. E. (2018). Dominant neuropeptide co-transmission in kisspeptin-GABA regulation of GnRH neuron firing driving ovulation. Journal of Neuroscience, 38(28), 6310-6322.

Pinilla, L., Aguilar, E., Dieguez, C., Millar, R. P., \& Tena-Sempere, M. (2012). Kisspeptins and reproduction: Physiological roles and regulatory mechanisms. Physiological Reviews, 92, 1235-1316. https:// doi.org/10.1152/physrev.00037.2010

Plant, T. M. (2012). A comparison of the neuroendocrine mechanisms underlying the initiation of the preovulatory LH surge in the human, Old World monkey and rodent. Frontiers in Neuroendocrinology, 33, 160-168. https://doi.org/10.1016/j.yfrne.2012.02.002

Plant, T. M., Ramaswamy, S., \& Dipietro, M. J. (2006). Repetitive activation of hypothalamic $\mathrm{G}$ protein-coupled receptor 54 with intravenous pulses of kisspeptin in the juvenile monkey (Macaca mulatta) elicits a sustained train of gonadotropin-releasing hormone discharges. Endocrinology, 147, 1007-1013. https://doi.org/10.1210/ en.2005-1261

Prague, J. K., \& Dhillo, W. S. (2015). Potential clinical use of kisspeptin. Neuroendocrinology, 102, 238-245. https://doi org/10.1159/000439133

Ralph, M. R., Foster, R. G., Davis, F. C., \& Menaker, M. (1990). Transplanted suprachiasmatic nucleus determines circadian period. Science, 247, 975-978. https://doi.org/10.1126/science.2305266

Rasri-Klosen, K., Simonneaux, V., \& Klosen, P. (2017). Differential response patterns of kisspeptin and RFamide-related peptide to photoperiod and sex steroid feedback in the Djungarian hamster (Phodopus sungorus). Journal of Neuroendocrinology, 29, e12529. https://doi.org/10.1111/jne.12529

Ratajczak, C. K., Boehle, K. L., \& Muglia, L. J. (2009). Impaired steroidogenesis and implantation failure in $\mathrm{Bmall}^{-/-}$mice. Endocrinology, 150, 1879-1885. https://doi.org/10.1210/ en.2008-1021

Reiter, R. J. (1993). The melatonin rhythm: Both a clock and a calendar. Experientia, 49, 654-664. https://doi.org/10.1007/BF01923947

Reppert, S. M., Godson, C., Mahle, C. D., Weaver, D. R., Slaugenhaupt, S. A., \& Gusella, J. F. (1995). Molecular characterization of a second melatonin receptor expressed in human retina and brain: The Mel1b melatonin receptor. Proceedings of the National Academy of Sciences of the United States of America, 92, 8734-8738. https://doi. org/10.1073/pnas.92.19.8734
Reppert, S. M., Weaver, D. R., \& Ebisawa, T. (1994). Cloning and characterization of a mammalian melatonin receptor that mediates reproductive and circadian responses. Neuron, 13, 1177-1185. https:// doi.org/10.1016/0896-6273(94)90055-8

Resuehr, D., Wildemann, U., Sikes, H., \& Olcese, J. (2007). E-box regulation of gonadotropin-releasing hormone $(\mathrm{GnRH})$ receptor expression in immortalized gonadotrope cells. Molecular and Cellular Endocrinology, 278, 36-43. https://doi.org/10.1016/j. mce.2007.08.008

Revel, F. G., Saboureau, M., Masson-Pévet, M., Pévet, P., Mikkelsen, J. D., \& Simonneaux, V. (2006). Kisspeptin mediates the photoperiodic control of reproduction in hamsters. Current Biology, 16, 1730-1735. https://doi.org/10.1016/j.cub.2006.07.025

Revel, F. G., Saboureau, M., Pévet, P., Mikkelsen, J. D., \& Simonneaux, V. (2006). Melatonin regulates type 2 deiodinase gene expression in the Syrian hamster. Endocrinology, 147, 4680-4687. https://doi. org/10.1210/en.2006-0606

Revel, F. G., Saboureau, M., Pévet, P., Simonneaux, V., \& Mikkelsen, J. D. (2008). RFamide-related peptide gene is a melatonin-driven photoperiodic gene. Endocrinology, 149, 902-912. https://doi. org/10.1210/en.2007-0848

Robertson, J. L., Clifton, D. K., de la Iglesia, H. O., Steiner, R. A., \& Kauffman, A. S. (2009). Circadian regulation of Kiss1 neurons: Implications for timing the preovulatory gonadotropin-releasing hormone/luteinizing hormone surge. Endocrinology, 150, 36643671. https://doi.org/10.1210/en.2009-0247

Roseweir, A. K., Kauffman, A. S., Smith, J. T., Guerriero, K. A., Morgan, K., Pielecka-Fortuna, J., ... Millar, R. P. (2009). Discovery of potent kisspeptin antagonists delineate physiological mechanisms of gonadotropin regulation. Journal of Neuroscience, 29, 39203929. https://doi.org/10.1523/JNEUROSCI.5740-08.2009

Ross, A. W., Helfer, G., Russell, L., Darras, V. M., \& Morgan, P. J. (2011). Thyroid hormone signalling genes are regulated by photoperiod in the hypothalamus of F344 rats. PLoS One, 6, e21351. https:// doi.org/10.1371/journal.pone.0021351

Ruby, N. F., Brennan, T. J., Xie, X., Cao, V., Franken, P., Heller, H. C., \& O'Hara, B. F. (2002). Role of melanopsin in circadian responses to light. Science, 298, 2211-2213. https://doi.org/10.1126/ science. 1076701

Russo, K. A., La, J. L., Stephens, S. B., Poling, M. C., Padgaonkar, N. A., Jennings, K. J., ... Kriegsfeld, L. J. (2015). Circadian control of the female reproductive axis through gated responsiveness of the RFRP-3 system to VIP signaling. Endocrinology, 156, 2608-2618. https://doi.org/10.1210/en.2014-1762

Sáenz de Miera, C., Hanon, E. A., Dardente, H., Birnie, M., Simonneaux, V., Lincoln, G. A., \& Hazlerigg, D. G. (2013). Circannual variation in thyroid hormone deiodinases in a short-day breeder. Journal of Neuroendocrinology, 25, 412-421. https://doi.org/10.1111/ jne. 12013

Sáenz de Miera, C., Monecke, S., Bartzen-Sprauer, J., Laran-Chich, M.-P., Pévet, P., Hazlerigg, D. G., \& Simonneaux, V. (2014). A circannual clock drives expression of genes central for seasonal reproduction. Current Biology, 24, 1500-1506. https://doi.org/10.1016/j. cub.2014.05.024

Sari, I. P., Rao, A., Smith, J. T., Tilbrook, A. J., \& Clarke, I. J. (2009). Effect of RF-amide-related peptide-3 on luteinizing hormone and follicle-stimulating hormone synthesis and secretion in ovine pituitary gonadotropes. Endocrinology, 150, 5549-5556. https://doi. org/10.1210/en.2009-0775 
Schally, A. V., Parlow, A. F., Carter, W. H., Saito, M., Bowers, C. Y., \& Arimura, A. (1970). Studies on the site of action of oral contraceptive steroids. II. Plasma LH and FSH levels after administration of antifertility steroids and LH-releasing hormone (LH-RH). Endocrinology, 86, 530-541. https://doi.org/10.1210/ endo-86-3-530

Seibel, M. M., Shine, W., Smith, D. M., \& Taymor, M. L. (1982). Biological rhythm of the luteinizing hormone surge in women. Fertility and Sterility, 37, 709-711. https://doi.org/10.1016/ S0015-0282(16)46288-6

Sellix, M. T. (2013). Clocks underneath: The role of peripheral clocks in the timing of female reproductive physiology. Frontiers in Endocrinology, 4(91), 1-6.

Sellix, M. T. (2015). Circadian clock function in the mammalian ovary. Journal of Biological Rhythms, 30, 7-19. https://doi. org/10.1177/0748730414554222

Sellix, M. T., Yoshikawa, T., \& Menaker, M. (2010). A circadian egg timer gates ovulation. Current Biology, 20, 266-267. https://doi. org/10.1016/j.cub.2010.01.045

Seminara, S. B., Messager, S., Chatzidaki, E. E., Thresher, R. R., Acierno, J. S., Shagoury, J. K., ... Colledge, W. H. (2003). The GPR54 gene as a regulator of puberty. New England Journal of Medicine, 349, 1614-1627. https://doi.org/10.1056/NEJMoa035322

Simonneaux, V., \& Bahougne, T. (2015). A multi-oscillatory circadian system times female reproduction. Frontiers in Endocrinology, 6(157), 1-15.

Simonneaux, V., Bahougne, T., \& Angelopoulou, E. (2017). Daily rhythms count for female fertility. Best Practice \& Research Clinical Endocrinology \& Metabolism, 31(5), 505-519. https://doi. org/10.1016/j.beem.2017.10.012

Simonneaux, V., \& Ribelayga, C. (2003). Generation of the melatonin endocrine message in mammals: A review of the complex regulation of melatonin synthesis by norepinephrine, peptides, and other pineal transmitters. Pharmacological Reviews, 55, 325-395. https://doi. org/10.1124/pr.55.2.2

Smarr, B. L., Gile, J. J., \& de la Iglesia, H. O. (2013). Oestrogen-independent circadian clock gene expression in the anteroventral periventricular nucleus in female rats: Possible role as an integrator for circadian and ovarian signals timing the luteinising hormone surge. Journal of Neuroendocrinology, 25, 1273-1279. https://doi. org/10.1111/jne.12104

Smarr, B. L., Morris, E., \& de la Iglesia, H. O. (2012). The dorsomedial suprachiasmatic nucleus times circadian expression of Kiss1 and the luteinizing hormone surge. Endocrinology, 153, 2839-2850. https:// doi.org/10.1210/en.2011-1857

Smith, J. T., Clay, C. M., Caraty, A., \& Clarke, I. J. (2007). KiSS-1 messenger ribonucleic acid expression in the hypothalamus of the ewe is regulated by sex steroids and season. Endocrinology, 148, 1150-1157. https://doi.org/10.1210/en.2006-1435

Smith, J. T., Coolen, L. M., Kriegsfeld, L. J., Sari, I. P., Jaafarzadehshirazi, M. R., Maltby, M., ... Lehman, M. N. (2008). Variation in kisspeptin and RFamide-related peptide (RFRP) expression and terminal connections to gonadotropin-releasing hormone neurons in the brain: A novel medium for seasonal breeding in the sheep. Endocrinology, 149, 5770-5782. https://doi.org/10.1210/en.2008-0581

Smith, J. T., Cunningham, M. J., Rissman, E. F., Clifton, D. K., \& Steiner, R. A. (2005). Regulation of Kiss1 gene expression in the brain of the female mouse. Endocrinology, 146, 3686-3692. https:// doi.org/10.1210/en.2005-0488
Smith, J. T., Dungan, H. M., Stoll, E. A., Gottsch, M. L., Braun, R. E., Eacker, S. M., ... Steiner, R. A. (2005). Differential regulation of KiSS-1 mRNA expression by sex steroids in the brain of the male mouse. Endocrinology, 146, 2976-2984. https://doi.org/10.1210/en.2005-0323

Smith, M. J., Jennes, L., \& Wise, P. M. (2000). Localization of the VIP receptor protein on $\mathrm{GnRH}$ neurons in the female rat. Endocrinology, 141, 4317-4320. https://doi.org/10.1210/endo.141.11.7876

Smith, J. T., Li, Q., Pereira, A., \& Clarke, I. J. (2009). Kisspeptin neurons in the ovine arcuate nucleus and preoptic area are involved in the preovulatory luteinizing hormone surge. Endocrinology, 150, 5530-5538. https://doi.org/10.1210/en.2009-0712

Smith, J. T., Popa, S. M., Clifton, D. K., Hoffman, G. E., \& Steiner, R. A. (2006). Kiss1 neurons in the forebrain as central processors for generating the preovulatory luteinizing hormone surge. Journal of Neuroscience, 26, 6687-6694. https://doi.org/10.1523/ JNEUROSCI.1618-06.2006

Smith, J. T., Shahab, M., Pereira, A., Pau, K. Y., \& Clarke, I. J. (2010). Hypothalamic expression of KISS1 and gonadotropin inhibitory hormone genes during the menstrual cycle of a non-human primate. Biology of Reproduction, 83, 568-577. https://doi.org/10.1095/ biolreprod.110.085407

Sun, Y., Shu, J., Kyei, K., \& Neal-Perry, G. S. (2012). Intracerebroventricular infusion of vasoactive intestinal peptide rescues the luteinizing hormone surge in middle-aged female rats. Frontiers in Endocrinology, 3(24, 1-9.

Takahashi, J. S. (2015). Molecular components of the circadian clock in mammals. Diabetes, Obesity \& Metabolism, 17, 6-11. https://doi. org/10.1111/dom.12514

Talbi, R., Klosen, P., Laran-Chich, M.-P., El Ouezzani, S., \& Simonneaux, V. (2016). Coordinated seasonal regulation of metabolic and reproductive hypothalamic peptides in the desert jerboa. The Journal of Comparative Neurology, 524, 3717-3728. https:// doi.org/10.1002/cne.24026

Tomikawa, J., Uenoyama, Y., Ozawa, M., Fukanuma, T., Takase, K., Goto, T., ... Tsukamura, H. (2012). Epigenetic regulation of Kiss1 gene expression mediating estrogen-positive feedback action in the mouse brain. Proceedings of the National Academy of Sciences of the United States of America, 109, E1294-E1301. https://doi. org/10.1073/pnas.1114245109

Tonsfeldt, K. J., Goodall, C. P., Latham, K. L., \& Chappell, P. E. (2011). Oestrogen induces rhythmic expression of the Kisspeptin-1 receptor GPR54 in hypothalamic gonadotrophin-releasing hormone-secreting GT1-7 cells. Journal of Neuroendocrinology, 23, 823-830. https://doi.org/10.1111/j.1365-2826.2011.02188.x

Urbanski, H. F., Doan, A., \& Pierce, M. (1991). Immunocytochemical investigation of luteinizing hormone-releasing hormone neurons in Syrian hamsters maintained under long or short days. Biology of Reproduction, 44, 687-692. https://doi.org/10.1095/ biolreprod44.4.687

van der Beek, E. M., Swarts, H. M., \& Wiegant, V. (1999). Central administration of antiserum to vasoactive intestinal peptide delays and reduces luteinizing hormone and prolactin surges in ovariectomized, estrogen-treated rats.Neuroendocrinology,69,227-237.

van der Beek, E. M., van Oudheusden, H. J., Buijs, R. M., van der Donk, H. A., van den Hurk, R., \& Wiegant, V. M. (1994). Preferential induction of c-fos immunoreactivity in vasoactive intestinal polypeptideinnervated gonadotropin-releasing hormone neurons during a steroid-induced luteinizing hormone surge in the female rat. Endocrinology, 134(6), 2636-2644. 
van der Beek, E. M., Wiegant, V. M., van der Donk, H. A., van den Hurk, R., \& Buijs, R. M. (1993). Lesions of the suprachiasmatic nucleus indicate the presence of a direct vasoactive intestinal polypeptide-containing projection to gonadotrophin-releasing hormone neurons in the female rat. Journal of Neuroendocrinology, 5, 137-144. https://doi.org/10.1111/j.1365-2826.1993.tb00373.x

van der Horst, G. T. J., Muijtjens, M., Kobayashi, K., Takano, R., Kanno, S., Takao, M., ... Yasui, A. (1999). Mammalian Cry1 and Cry2 are essential for maintenance of circadian rhythms. Nature, 398, 627-630. https://doi.org/10.1038/19323

Vaněcek, J., Pavlík, A., \& Illnerová, H. (1987). Hypothalamic melatonin receptor sites revealed by autoradiography. Brain Research, 435, 359-362. https://doi.org/10.1016/0006-8993(87)91625-8

Vida, B., Deli, L., Hrabovszky, E., Kalamatianos, T., Caraty, A., Coen, C. W., ... Kalló, I. (2010). Evidence for suprachiasmatic vasopressin neurones innervating kisspeptin neurones in the rostral periventricular area of the mouse brain: Regulation by oestrogen. Journal of Neuroendocrinology, 22, 1032-1039. https://doi. org/10.1111/j.1365-2826.2010.02045.X

Watanabe, Y., Uenoyama, Y., Suzuki, J., Takase, K., Suetomi, Y., Ohkura, S., ... Tsukamura, H. (2014). Oestrogen-induced activation of preoptic kisspeptin neurones may be involved in the luteinising hormone surge in male and female Japanese monkeys. Journal of Neuroendocrinology, 26, 909-917. https://doi.org/10.1111/ jne. 12227

Watanabe, M., Yasuo, S., Watanabe, T., Yamamura, T., Nakao, N., Ebihara, S., \& Yoshimura, T. (2004). Photoperiodic regulation of type 2 deiodinase gene in Djungarian hamster: Possible homologies between avian and mammalian photoperiodic regulation of reproduction. Endocrinology, 145, 1546-1549. https://doi.org/10.1210/ en.2003-1593

Weaver, D. R., Liu, C., \& Reppert, S. M. (1996). Nature's knockout: The Mel1b receptor is not necessary for reproductive and circadian responses to melatonin in Siberian hamsters. Molecular Endocrinology, 10, 1478-1487.

Weems, P. W., Goodman, R. L., \& Lehman, M. N. (2015). Neural mechanisms controlling seasonal reproduction: Principles derived from the sheep model and its comparison with hamsters. Frontiers in Neuroendocrinology, 37, 43-51. https://doi.org/10.1016/j. yfrne.2014.12.002

Weems, P., Smith, J., Clarke, I. J., Coolen, L. M., Goodman, R. L., \& Lehman, M. N. (2017). Effects of season and estradiol on KNDy neuron peptides, colocalization with D2 dopamine receptors, and dopaminergic inputs in the ewe. Endocrinology, 158, 831-841. https://doi.org/10.1210/en.2016-1830

Wiegand, S. J., Terasawa, E., Bridson, W. E., \& Goy, R. W. (1980). Effects of discrete lesions of preoptic and suprachiasmatic structures in the female rat. Neuroendocrinology, 31, 147-157. https:// doi.org/10.1159/000123066

Williams, W. P., Jarjisian, S. G., Mikkelsen, J. D., \& Kriegsfeld, L. J. (2011). Circadian control of kisspeptin and a gated GnRH response mediate the preovulatory luteinizing hormone surge. Endocrinology, 152, 595-606. https://doi.org/10.1210/en.2010-0943
Wintermantel, T. M., Campbell, R. E., Porteous, R., Bock, D., Gröne, H. J., Todman, M. G., ... Herbison, A. E. (2006). Definition of estrogen receptor pathway critical for estrogen positive feedback to gonadotropin-releasing hormone neurons and fertility. Neuron, 52(2), 271-280. https://doi.org/10.1016/j.neuron.2006.07.023

Wittkowski, W., Bergmann, M., Hoffmann, K., \& Pera, F. (1988). Photoperiod-dependent changes in TSH-like immunoreactivity of cells in the hypophysial pars tuberalis of the Djungarian hamster, Phodopus sungorus. Cell and Tissue Research, 251, 183-187. https://doi.org/10.1007/BF00215463

Xu, Z., Kaga, S., Tsubomizu, J., Fujisaki, J., Mochiduki, A., Sakai, T., ... Adachi, A. A. (2011). Circadian transcriptional factor DBP regulates expression of Kiss1 in the anteroventral periventricular nucleus. Molecular and Cellular Endocrinology, 339, 90-97. https:// doi.org/10.1016/j.mce.2011.03.020

Yasuo, S., Yoshimura, T., Ebihara, S., \& Korf, H.-W. (2009). Melatonin transmits photoperiodic signals through the MT1 melatonin receptor. Journal of Neuroscience, 29, 2885-2889. https://doi.org/10.1523/ JNEUROSCI.0145-09.2009

Yeo, S.-H., \& Herbison, A. E. (2011). Projections of arcuate nucleus and rostral periventricular kisspeptin neurons in the adult female mouse brain. Endocrinology, 152, 2387-2399. https://doi.org/10.1210/ en.2011-0164

Yip, S. H., Boehm, U., Herbison, A. E., \& Campbell, R. E. (2015). Conditional viral tract tracing delineates the projections of the distinct kisspeptin neuron populations to gonadotropin-releasing hormone (GnRH) neurons in the mouse. Endocrinology, 156, 25822594. https://doi.org/10.1210/en.2015-1131

Yoshikawa, T., Sellix, M., Pezuk, P., \& Menaker, M. (2009). Timing of the ovarian circadian clock is regulated by gonadotropins. Endocrinology, 150, 4338-4347. https://doi.org/10.1210/ en.2008-1280

Yoshimura, T. (2013). Thyroid hormone and seasonal regulation of reproduction. Frontiers in Neuroendocrinology, 34, 157-166. https:// doi.org/10.1016/j.yfrne.2013.04.002

Yoshimura, T., Yasuo, S., Watanabe, M., Iigo, M., Yamamura, T., Hirunagi, K., \& Ebihara, S. (2003). Light-induced hormone conversion of T4 to T3 regulates photoperiodic response of gonads in birds. Nature, 426, 178-181. https://doi.org/10.1038/nature02117

Zeleznik, A. J., \& Plant, T. (2015). Control of the menstrual cycle. In T. M. Plant \& A. J. Zeleznic (Eds.), Knobil and Neill's physiology of reprodution (4th ed., Chp. 28, pp. 1307-1362). Amsterdam, the Netherlands: Academic Press.

Zhao, S., \& Kriegsfeld,L. J.(2009). Daily changes in GT1-7 cell sensitivity to GnRH secretagogues that trigger ovulation. Neuroendocrinology, 89, 448-457. https://doi.org/10.1159/000192370

How to cite this article: Simonneaux V. A Kiss to drive rhythms in reproduction. Eur J Neurosci. 2018;00:1-22.https://doi.org/10.1111/ejn.14287 